\title{
RESULTS OF MONITORING FOR PCDDs and PCDFs IN AMBIENT AIR AT MCMURDO STATION, ANTARCTICA
}

\author{
by \\ Robert M. Lugar \\ EG\&G Idaho, Inc. \\ Environmental Technology Unit \\ Idaho Falls, ID 83415-1406 \\ September 1993
Interagency Agreement No. DPP-9102787
with
U.S. Department of Energy Idaho Field Office Idaho Falls, ID 83402 \\ Project officer \\ Dr. Jane Dionne \\ Environmental officer \\ Office of Polar Programs \\ National Science Foundation \\ Washington, DC 20550
}




\section{DISCLAIMER}

Portions of this document may be illegible in electronic image products. Images are produced from the best available original document. 


\title{
RESULTS OF MONITORING FOR PCDDs and PCDFs IN AMBIENT AIR AT MCMURDO STATION, ANTARCTICA
}

\author{
by \\ Robert M. Lugar \\ EG\&G Idaho, Inc. \\ Environmental Technology Unit \\ Idaho Falls, ID 83415-1406
}

September 1993
Interagency Agreement No. DPP-9102787 with
U.S. Department of Energy
Idaho Field office
Idaho Falls, ID 83402

\author{
Project Officer \\ Dr. Jane Dionne \\ Environmental officer \\ Office of Polar Programs \\ National Science Foundation \\ Washington, DC 20550
}




\begin{abstract}
This report presents the results of ambient air monitoring for polychlorinated dibenzo-p-dioxins (PCDDs) and polychlorinated dibenzofurans (PCDFs) performed during the 1992-1993 austral summer in the vicinity of McMurdo Station, Antarctica. Fifteen air samples were collected from four different locations for determination of the presence and concentration of PCDD/PCDF compounds. General Metal Works Inc. PS-1 air samplers equipped with polyurethane foam (PUF) with a sample flow rate of approximately $0.27 \mathrm{~m}^{3} / \mathrm{min}$. were used to collect air samples. Sampling site selection, sampling procedures, and quality assurance procedures used were consistent with U.S. Environmental Protection Agency guidance for local ambient air quality networks. PCDD/PCDF compounds were not detected at the predominantly upwind location and at a more remote site on Black Island. Trace levels of only a few PCDD/PCDF congeners were detected sporadically at a location approximately 500 meters downwind of the station. The most frequent, most varied, and highest levels of PCDDs/PCDFs were measured at a "downtown" location, where concentrations of total PCDDs ranged from 0.27 to $1.80 \mathrm{pg} / \mathrm{m}^{3}$ and total PCDFs from less than 0.1 to $2.77 \mathrm{pg} / \mathrm{m}^{3}$. Results from the remote $\mathrm{Black}$ Island site indicate that the background Antarctic air is still "free" of PCDD/PCDF compounds (not detectable at current method detection limits). The initial baseline effort demonstrated that site selection and sampling equipment performance were satisfactory, provided useful data for assessing the impact of McMurdo operations on the local ambient air quality, and provided baseline data for assessing the Antarctica continental air quality.
\end{abstract}

\title{
DISCLAIMER
}

This report was prepared as an account of work sponsored by an agency of the United States Government. Neither the United States Government nor any agency thereof, nor any of their employees, makes any warranty, express or implied, or assumes any legal liability or responsibility for the accuracy, completeness, or usefulness of any information, apparatus, product, or process disclosed, or represents that its use would not infringe privately owned rights. Reference herein to any specific commercial product, process, or service by trade name, trademark, manufacturer, or otherwise does not necessarily constitute or imply its endorsement, recommendation, or favoring by the United States Government or any agency thereof. The views and opinions of authors expressed herein do not necessarily state or reflect those of the United States Government or any agency thereof. 


\section{Results of Monitoring for PCDDs and PCDFs in Ambient Air at McMurdo Station, Antarctica}

\section{Introduction}

McMurdo Station $\left(77^{\circ} 51^{\prime}\right.$ South $166^{\circ} 40^{\prime}$ East) is the largest human community in Antarctica. It is a coastal station constructed on low ash and volcanic hills at the southern tip of Ross Is1and. McMurdo serves as the primary logistics and staging facility for airborne resupply of inland research stations and supports a wide variety of scientific research sponsored by the United States National Science Foundation's Antarctic Program. The austral winter (MarchSeptember) population in 1992 was 257, and the austral summer (OctoberFebruary) population exceeded 1,100. The station consists of over 100 structures, and numerous equipment laydown and storage areas. A nearby skiway airport and sea-ice runway serve fixed wing aircraft for flights to the Antarctic mainland, as well as flights to and from New Zealand. Emissions of atmospheric pollutants at or near McMurdo result from a variety of sources, including: boilers, furnaces, space heaters, electric generators, motor vehicle engines, incinerators, fugitive dust, petroleum storage tank vapors, aircraft operations, and ships. The major fixed air emission source is believed to be the electric generation plant. Tables 1 and 2 summarize the major source categories and estimated air pollutant/products of combustion emissions at McMurdo.

A report on the National Science Foundation (NSF) implementation of a strategy to comply with environmental law in Antarctica (NSF 1989) established the need to assess the environmental impact of air emissions at McMurdo Station and other U.S. Stations. In addition, the recent Protocol on Environmental Protection to the Antarctic Treaty (NSF 1991) and implementation of interim incineration during the 1992-1993 austral summer season of selected solid wastes at McMurdo further underlined the need to implement an ambient air monitoring network. Incineration at McMurdo ceased on March 22, 1993. In 1992 an ambient air monitoring plan for Mcmurdo was prepared that established the objectives of the monitoring effort as: (1) to determine the highest concentrations of pollutants expected to occur in the area covered by the network, (2) to determine representative concentrations of selected air pollutants in areas of high population density (3) to determine the impact on ambient pollution levels of significant sources or source categories, and (4) to determine background levels of selected air pollutants (Lugar, 1992).

The objectives and performance criteria established for the monitoring network were consistent with the intent of United States Environmental Protection Agency's (EPA) State and Local Air Monitoring Stations (SLAMS) objectives and network design (40CFR58, Appendix D). Quality assurance and quality control aspects of the PCDD/PCDF monitoring effort were generally consistent with EPA sampling procedures (EPA 1986) and the EPA Quality Assurance Handbook (EPA 1977). Co-location of samplers was not feasible during this initial baseline effort due to the limited number of samplers and the relatively short summer season. A variety of air pollutants, including many for which the EPA has 
Table 1. Comparison of Sources of Products of Combustion at McMurdo Station (metric tons per year)

\begin{tabular}{|c|c|c|c|c|c|c|}
\cline { 2 - 6 } \multicolumn{1}{c|}{} & $\begin{array}{c}\text { Electric } \\
\text { Generation }\end{array}$ & $\begin{array}{c}\text { Water } \\
\text { Distribution }\end{array}$ & $\begin{array}{c}\text { Space } \\
\text { Heating }\end{array}$ & $\begin{array}{c}\text { Surface } \\
\text { Vehicles }\end{array}$ & $\begin{array}{c}\text { Waste } \\
\text { Incineration }\end{array}$ & TOTAL \\
\hline $\mathrm{CO}_{2}$ & 12341 & 6743 & 2023 & 2862 & 201 & 24170 \\
$\mathrm{H}_{2} \mathrm{O}$ & 4114 & 2620 & 786 & 1124 & 188 & 8832 \\
$\mathrm{SO}_{2}$ & 7.8 & 4.3 & 1.3 & 0.064 & 0.086 & 13.6 \\
$\mathrm{NO}_{\times}$ & 50.6 & 4.2 & 1.3 & 6.9 & 0.12 & 63.1 \\
$\mathrm{Part./HC}$ & 4.81 & 1.2 & 0.64 & 5.08 & 0.0068 & 11.7 \\
$\mathrm{HCl}$ & $<0.45$ & $<0.23$ & $<0.045$ & $<0.0045$ & 0.04 & $<0.77$ \\
\hline
\end{tabular}

1 data based on emission factor estimates, not on actual monitoring data

2 after scrubber (est imated)

Adopted from: Pearson 1991. 
Table 2. Estimated Annual Air Pollutant Emissions at McMurdo Station

\begin{tabular}{|c|c|c|c|c|c|c|c|}
\hline \multirow[b]{2}{*}{ Source Category } & \multicolumn{2}{|c|}{ Annual Emission Basis } & \multicolumn{5}{|c|}{ Pollutant Emission Rate (tons ${ }^{a} / y r$ ) } \\
\hline & Units & Quantity & $\mathrm{SO}_{2}$ & $\mathrm{NO}_{2}$ & $P M-10$ & $\mathrm{HC}$ & $\mathrm{CO}$ \\
\hline $\begin{array}{l}\text { Aircraft Operations } \\
\text { LC-130 and } C-130 \\
C-141 \\
C-5 B\end{array}$ & $\begin{array}{l}\text { LTOs } \\
\text { LTOs } \\
\text { LTOs }\end{array}$ & $\begin{array}{l}328 \\
25 \\
5^{c}\end{array}$ & $\begin{array}{l}0.6 \\
0.004 \\
0.001\end{array}$ & $\begin{array}{l}2.9 \\
0.2 \\
0.1\end{array}$ & $\begin{array}{l}0.4 \\
0.01 \\
\text { neg. }\end{array}$ & $\begin{array}{l}8.9 \\
1.8 \\
0.2\end{array}$ & $\begin{array}{r}14.0 \\
2.2 \\
0.5\end{array}$ \\
\hline Subtotal & & & 0.7 & 3.2 & 0.4 & 11 & 17 \\
\hline $\begin{array}{l}\text { Internal combustion engines } \\
\text { Diesel (stationary and mobile) } \\
\text { Gasoline (mobile) }\end{array}$ & $\begin{array}{l}1000 \mathrm{gal}^{\mathrm{d}} \\
1000 \mathrm{gal} \\
\end{array}$ & $\begin{array}{l}1500 \\
150 \\
\end{array}$ & $\begin{array}{r}23.0 \\
0.4 \\
\end{array}$ & $\begin{array}{r}350.0 \\
7.7 \\
\end{array}$ & $\begin{array}{r}25.0 \\
0.5 \\
\end{array}$ & $\begin{array}{l}28.0 \\
15.0^{\mathrm{e}}\end{array}$ & $\begin{array}{r}77.0 \\
300.0 \\
\end{array}$ \\
\hline $\begin{array}{l}\text { External combustion } \\
\text { Boilers, furnaces, etc. }\end{array}$ & $1000 \mathrm{gal}$ & 1300 & 4.6 & 13.0 & $1.6^{f}$ & $1.6^{\mathrm{f}}$ & 3.3 \\
\hline Open burning (landfill) & \multicolumn{2}{|c|}{ DISCONTINUED } & 0 & 0 & 0 & 0 & 0 \\
\hline $\begin{array}{l}\text { Storage tanks (evaporation) } \\
\text { JP-8 } \\
\text { Gasoline }\end{array}$ & & & & & & $\begin{array}{l}0.2 \\
7.2\end{array}$ & \\
\hline TOTAL McMurdo. & & & 29 & 374 & 28 & 63 & 398 \\
\hline
\end{tabular}

a One ton equals 0.907 metric tons. English units are used in this table because regulatory emission limits and U.S. EPA emission factors are given in English units.

b Landing take-off cycles.

d Only two C-5B flights to McMUrdo were reported for the 1989-90 summer season, but up to five flights per season would be typical.

One gallon equals 3.785 liters.

e Sum of exhaust, evaporative, and crankcase emissions.

Used emission factors from residential furnaces.

Source: NSF 1991. 
established National Ambient Air Quality Standards (NAAQS), were selected for monitoring. One pollutant of concern selected for monitoring for which there are no NAAQS was dioxin/furan compounds (PCDDs and PCDFs). Utilizing historical wind data, a local sampling network consisting of three locations was selected for the collection of samples. The locations were selected after field reconnaissance. They were based on 1) objectives out lined in the monitoring plan, 2) the availability of electrical power, and 3) operational support requirements and location of major emission sources. The three local sites selected were: 1) 8-Site for the predominantly upwind location, 2) Hut Point for the predominantly downwind site, and 3) Central McMurdo, near building 155, as the "worst case urban" location (See Figure 1). Black Island, a remote location approximately 33 kilometers south-southwest of McMurdo, was selected to provide background or "control" data, and the sample collected from there was considered representative of the continental air quality.

\section{Methods}

Samples were collected in accordance with EPA Reference Method Tog, Method for the Determination of Polychlorinated Dibenzo-p-Dioxins (PCDDs) in Ambient Air Using High-Resolution Gas Chromatography/High-Resolution Mass Spectrometry (HRGC/HRMS). Samples were collected using a General Metal Works Model PS-1 PUF Sampler with a flowrate of approximately $0.27 \mathrm{~m}^{3} / \mathrm{min}$. The method consists of sampling ambient air via an inlet glass fiber filter followed by a glass cartridge filled with a polyurethane foam (PUF) plug. Flow calibration curves were prepared for each sampler prior to the collection of the first sample and following the collection of the last sample. An elapsed time indicator on the sampler provided a record of sampling time. The PUF plugs were cleaned and then spiked with known amount of ${ }^{13} \mathrm{C}_{12}-1,2,3,4-\mathrm{TCDD}$ by the EPA Environmental Chemistry Laboratory (ECL) at Stennis Space Center, Mississippi. Following sample collection, the filters and PUF plugs were extracted by the same laboratory, and the extracts then analyzed by the EPA Atmospheric Research and Exposure Assessment Laboratory (AREAL) in Research Triangle Park, North Carolina. Field blanks, laboratory method blanks, and fortified laboratory method blanks (laboratory spikes) were utilized for quality assurance purposes.

Between 12NOV92 and 24JAN93, 14 air samples were collected at the three local McMurdo sample sites. During the week of 11 NOV92, a single sample was collected from Black Island. Because this was the first known attempt to measure PCDD/PCDF compounds in the Antarctic ambient air, and no information was available on existing concentrations, the total elapsed sample times, and associated sample volumes, were varied between 24 and 48 hours $\left(392 \mathrm{~m}^{3}\right.$ and 778 $\mathrm{m}^{3}$, respectively) for the local McMurdo samples. The Black Island elapsed sampling time was approximately 166 hours $\left(2586 \mathrm{~m}^{3}\right)$ due to the anticipated pristine air quality at that location. The glass fiber filters and associated PUF plugs were retrieved as soon as possible after the conclusion of the sampling, wrapped in aluminum foil and placed in a resealable plastic bag to minimize exposure to the ambient air and light. The samples were stored at room temperature at McMurdo until a sufficient number of samples had accumulated to warrant shipment to the analytical laboratory. Two shipments 
were made during the course of this work to the EPA ECL in Mississippi for sample preparation prior to analysis.

The analytical procedures used (Harless, 1992 and the revised EPA Reference Method T09) are similar to those in EPA Method 8290. A brief description is provided here. Sample preparations were performed on a set of 12 samples which consisted of 9 test samples, field blank, method blank, and a fortified method blank. Each respective glass fiber filter and PUF were combined, spiked with nine ${ }^{13} \mathrm{C}_{12}$ - Tabeled PCDD/PCDF internal standards and then Soxhlet extracted with benzene for sixteen hours. Each extract was then subjected to an acid base clean-up procedure followed by clean-up on micro columns of silica jel, alumina, and carbon, Each extract was concentrated to $0.5 \mathrm{~mL}$. An aliquot of the recovery standard containing $0.5 \mathrm{ng}{ }^{37} \mathrm{Cl}_{4}-2,3,7,8-\mathrm{TCDD}$ was then spiked to each extract. The extracts were concentrated to $30 \mu 1$, quantitatively transferred to respective $2 \mathrm{~mm}$ i.d. $X 75 \mathrm{~mm}$ glass tubes, and fire sealed for shipment to EPA AREAL at Research Triangle Park, North Carolina for analysis.

A Finnigan MAT 90 HRGC-HRMS system operating in the electron impact ionization and multiple ion detection mode at 7000 to 10000 mass resolution was used for the analysis of samples. Chromatographic resolution of components was accomplished using a $30 \mathrm{~m} \mathrm{DB-5}$ fused silica capillary column and/or a $60 \mathrm{~m} \mathrm{SP}$ 2331 fused silica capillary column for resolution of 2,3,7,8-substituted congeners, isomer specific analysis. The peak areas of the exact masses of the molecular ion clusters of the labeled and unlabeled PCDDs and PCDFs and respective response factors were used for quantification purposes. The ${ }^{37} \mathrm{Cl}_{4}$ 2,3,7,8-TCDD spiked to the sample extract prior to final concentration, was used to determine the method efficiency, recovery of the nine ${ }^{3} C_{12}-1$ abeled internal standards. The recovery of the ${ }^{13} C_{12}-1,2,3,4-T C D D$ that was spiked to the PS-1 filter prior to ambient air sampling was used to determine the PS-1 air sampler collection and retention efficiency for the sampling period. The nine labeled PCDD and PCDF internal standards and respective response factors were used for quantification of unlabeled PCDDs and PCDFs and for determination of method detection limits (MDLS). For example, the ${ }^{13} \mathrm{C}_{12}$ $2,3,7,8-T C D D$ was used to quant ify the 2,3,7,8-TCDD isomer and a11 other TCDD isomers present or to determine the MDLs. The ${ }^{13} C_{12}-O C D D$ was used in a similar manner for OCDD and OCDF.

The data achieved for a set of samples was evaluated using defined analytical criteria and $Q A / Q C$ criteria and requirements. The acceptance criteria for data include: acceptable chlorine isotope ratios, retention time, signal to noise ratio, PS-1 collection and retention efficiency, method efficiency, accuracy and precision achieved for laboratory method spike or control sample, method blank free of significant PCDD and PCDF contamination, analysis that confirmed the absence of chlorinated diphenylethers.

\section{Results}

PCDD/PCDF concentrations in ambient air at MCMurdo were reliably measured using the stated methods and equipment. All results generated for each set of the test samples and $Q A / Q C$ samples met the acceptance criteria. One sample 
was lost during extraction. Eight out of a total of 14 samples successfully analyzed indicated the presence of a few PCDD/PCDF compounds in the sub $\mathrm{pg} / \mathrm{m}^{3}$ range. A11 PCDD/PCDF congeners were detectable in one of the samples. Table 3 provides a summary for a 11 samples collected; the values reported have been blank-corrected. Table 3 also includes total PCDD and total PCDF values, Toxicity Equivalent Factors (TEFs) and associated 2,3,7,8-TCDD Equivalent Concentrations (TEQs). PCDD/PCDFs were detected in ambient air only at the central McMurdo and Hut Point locations. The average TEQ concentration for the five samples collected at the central McMurdo location was $0.0153 \mathrm{pg} / \mathrm{m}^{3}$. For comparison purposes, this level is well below the State of Connecticut ambient air PCDDs/PCDFs standard of $1.0 \mathrm{pg} / \mathrm{m}^{3}$ expressed as 2,3,7,8-TCDD equivalents. The results from the predominantly upwind 8 -Site location and remote Black Island indicate no detectable PCDD/PCDF compounds present.

The few congeners detected in the Hut Point and central McMurdo samples were at concentrations very near the method detection limit, with the exception of one sample from the central McMurdo site collected on 28-30DEC92. This sample contained a notable variety of PCDD/PCDF congeners at levels well above the detection limits, and provides reliable evidence that PCDD/PCDF compounds were present in the ambient air. The total PCDD and PCDF concentrations of this sample were $1.8 \mathrm{pg} / \mathrm{m}^{3}$ and $2.77 \mathrm{pg} / \mathrm{m}^{3}$, respectively. These concentrations are comparable to levels measured by other researchers in suburban and urban areas (See Table 4). The average total PCDD/PCDF level based on five samples collected at central McMurdo during the 1992-1993 austral summer were more typical of a "cleaner" suburban area, and the average concentrations at Hut Point were comparable to rural concentrations in the United States (See Table 4).

To normalize concentrations and toxicity of the various PCDD/PCDF congeners, TEFs are used to calculate Toxicity Equivalents (TEQs), which represent the equivalent concentration of 2,3,7,8-TCDD. Total TEQ values for each of the eight samples with detectable quantities of PCDD/PCDFs are displayed graphically on Figure 2. TEQ values ranged from $0.00056 \mathrm{pg} / \mathrm{m}^{3}$ to 0.07442 $\mathrm{pg} / \mathrm{m}^{3}$ for central McMurdo, and from zero (none detected) to $0.00216 \mathrm{pg} / \mathrm{m}^{3}$ at Hut Point. For comparison purposes, these values are well below the 2-year average 2,3,7,8-TCDD equivalent concentration of total PCDD/PCDF measured in ambient air at Rutland, Vermont. (EPA, 1991)

Graphical profiles of PCDD/PCDF congeners were produced from the data to compare patterns between samples and potential sources (See Figures 3 through 11). Four of the five samples from the central McMurdo location demonstrated very similar profiles of HpCDDs and OCDDs as the only homologues present in the samples. The Hut Point samples that contained detectable quantities of PCDD/PCDF also indicated the presence of these same two homologues at lower concentrations. The Hut Point sample collected on 23-24JAN93 exhibited an elevated level of octa-chlorodibenzofuran (OCDF).

The 28-30DEC92 central McMurdo sample was notable not only in the elevated concentrations of PCDO/PCDF (relative to all other samples,) but also in the greater variety of congeners present. The exact source or sources of PCDDs/PCDFs detected during this sampling period cannot be definitively determined; however, the interim incinerator is one potential source. 
Table 3. Summary of PUF dioxin/furan ambient air samples from McMurdo, Antarctica

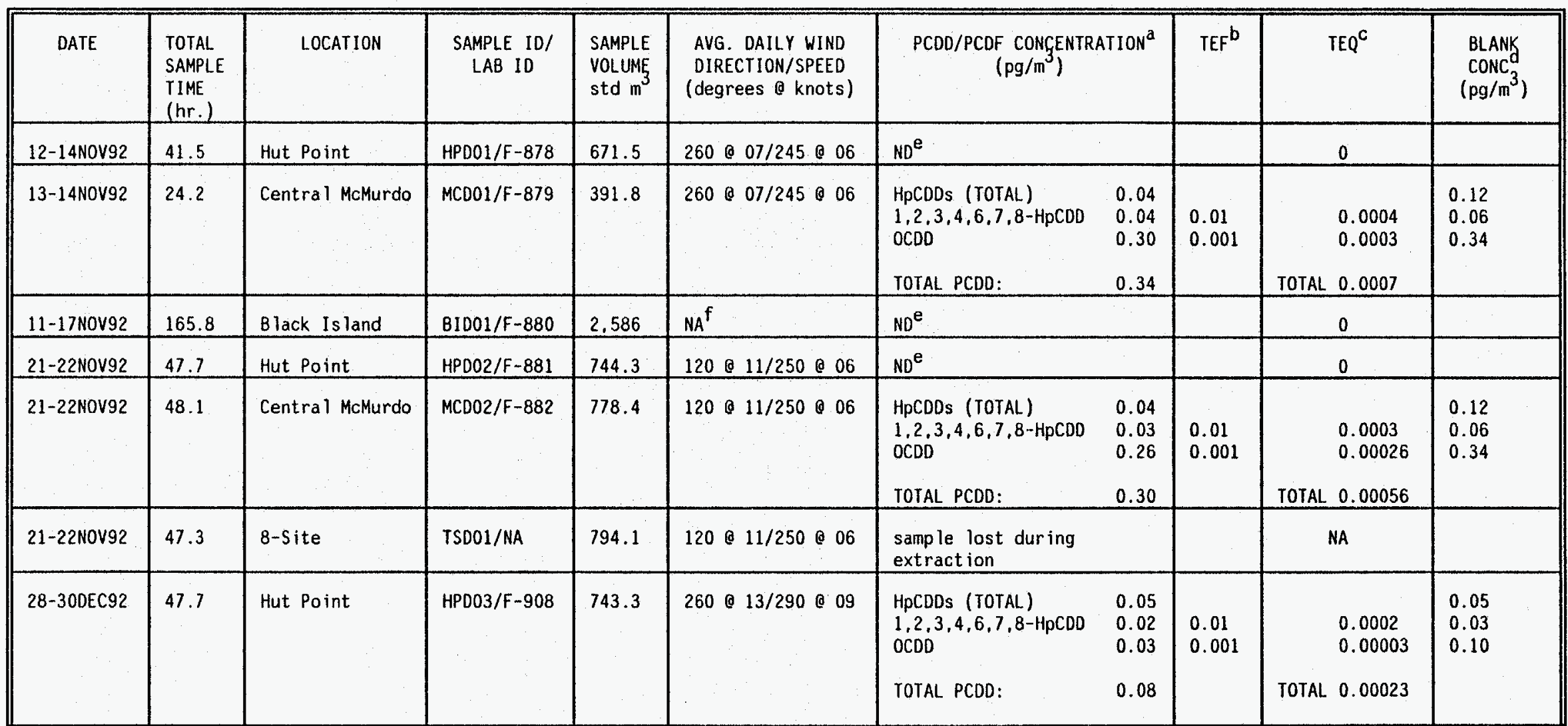


Table 3. - continued

\begin{tabular}{|c|c|c|c|c|c|c|c|c|c|c|}
\hline DATE & $\begin{array}{l}\text { TOTAL } \\
\text { SAMPLE } \\
\text { TIME } \\
\text { (hr.) }\end{array}$ & LOCATION & $\begin{array}{l}\text { SAMPLE ID/ } \\
\text { LAB ID }\end{array}$ & $\begin{array}{l}\text { SAMPLE } \\
\text { VOLUME } \\
\text { std } m^{3}\end{array}$ & $\begin{array}{l}\text { AVG. DAILY WIND } \\
\text { DIRECTION/SPEED } \\
\text { (degrees a knots) }\end{array}$ & \multicolumn{2}{|c|}{$\begin{array}{l}\text { PCDD/PCDF CONCENTRATION } \\
\left(\mathrm{pg} / \mathrm{m}^{3}\right)\end{array}$} & $T_{E F}^{b}$ & $\operatorname{TE} Q^{c}$ & $\begin{array}{l}\text { BLANK } \\
\text { CONC }_{3} \\
\left(\mathrm{pg} / \mathrm{m}^{3}\right)\end{array}$ \\
\hline $28-300 E C 92$ & 47.7 & Central McMurdo & $M C D 03 / F-901$ & 744.3 & $260 @ 13 / 290 @ 09$ & $\begin{array}{l}\text { TCDDs (TOTAL) } \\
\text { PeCdds (TOTAL) } \\
\text { HxCDDs (TOTAL) } \\
1,2,3,6,7,8-\mathrm{H} \times C D D \\
1,2,3,7,8,9-\mathrm{H} \times \mathrm{CDD} \\
\text { HpCDDs (TOTAL) } \\
1,2,3,4,6,7,8-\mathrm{HPCDD} \\
\text { OCDD } \\
\text { TCDFs (TOTAL) } \\
2,3,7,8-\text { TCDF } \\
\text { PeCDF (TOTAL) } \\
1,2,3,7,8-\mathrm{PeCDF} \\
2,3,4,7,8-\mathrm{PeCDF} \\
\text { HXCDFs (TOTAL) } \\
1,2,3,4,7,8-\mathrm{H} \times \mathrm{CDF} \\
1,2,3,6,7,8-\mathrm{H} \times \mathrm{COF} \\
\text { HpCDFs (TOTAL) } \\
1,2,3,4,6,7,8-\mathrm{HpCDF} \\
\text { OCDF } \\
\text { TOTAL PCDD: } \\
\text { IOTAL PCDF: }\end{array}$ & $\begin{array}{l}0.48 \\
0.42 \\
0.41 \\
0.04 \\
0.04 \\
0.18 \\
0.10 \\
0.31 \\
1.51 \\
0.11 \\
0.90 \\
0.07 \\
0.08 \\
0.23 \\
0.05 \\
0.05 \\
0.12 \\
0.09 \\
0.01 \\
1.80 \\
2.77 \\
\end{array}$ & $\begin{array}{l}0.10 \\
0.10 \\
0.01 \\
0.001 \\
0.1 \\
0.05 \\
0.5 \\
0.1 \\
0.1 \\
0.01 \\
0.001\end{array}$ & $\begin{array}{ll} & 0.004 \\
0.004 & \\
0.001 \\
0.00001 \\
\\
0.011 \\
0.0035 \\
0.04 \\
0.005 \\
0.005 \\
0.0009 \\
0.00001 \\
\text { TOTAL } 0.07442\end{array}$ & $\begin{array}{l}\text { ND }(0.01) \\
\text { ND }(0.02) \\
\text { ND }(0.03) \\
\text { ND }(0.03) \\
\text { ND }(0.03) \\
0.05 \\
0.03 \\
0.10 \\
\text { ND }(0.03) \\
\text { ND }(0.03) \\
\text { ND }(0.009) \\
\text { ND }(0.009) \\
\text { ND }(0.009) \\
\text { ND }(0.01) \\
\text { ND }(0.01) \\
\text { ND(0.01) } \\
\text { ND(0.02) } \\
\text { ND }(0.02) \\
0.03\end{array}$ \\
\hline 28-30DEC92 & 48.1 & 8-Site & TSD02/F-906 & 778.7 & $260013 / 290 @ 09$ & $\mathrm{ND}^{\mathrm{e}}$ & & & 0 & \\
\hline 20-22JAN93 & 48.4 & Hut Point & HPD04/F-910 & 783.4 & $030 @ 18 / 310 @ 10$ & $\begin{array}{l}\text { HPCOD (TOTAL) } \\
1,2,3,4,6,7,8-\mathrm{HPCDD} \\
\text { OCDD } \\
\text { TOTAL PCDD: }\end{array}$ & $\begin{array}{l}0.06 \\
0.03 \\
0.10 \\
0.16 \\
\end{array}$ & $\begin{array}{l}0.01 \\
0.001\end{array}$ & $\begin{array}{r}0.0003 \\
0.0001 \\
\text { TOTAL } 0.0004 \\
\end{array}$ & $\begin{array}{l}0.05 \\
0.03 \\
0.10\end{array}$ \\
\hline 20-22JAN93 & 48.4 & Central McMurdo & $M C D 04 / F-907$ & 813.3 & $030 @ 18 / 310 @ 10$ & $\begin{array}{l}\text { HpCDDs (TOTAL) } \\
1,2,3,4,6,7,8-\mathrm{HPCDO} \\
\text { OCDO } \\
\text { TOTAL PCDD: }\end{array}$ & $\begin{array}{l}0.08 \\
0.03 \\
0.28 \\
0.36 \\
\end{array}$ & $\begin{array}{l}0.01 \\
0.001\end{array}$ & $\begin{aligned} & 0.0003 \\
& 0.00028 \\
& \text { TOTAL } 0.00058 \\
&\end{aligned}$ & $\begin{array}{l}0.05 \\
0.03 \\
0.10\end{array}$ \\
\hline 20-22.JAN93 & 47.9 & 8-Site & TSD03/F-909 & 804.9 & $030 @ 18 / 310 @ 10$ & $N D^{e}$ & & & 0 & \\
\hline
\end{tabular}


Table 3. - continued

\begin{tabular}{|c|c|c|c|c|c|c|c|c|c|c|}
\hline DATE & $\begin{array}{l}\text { TOTAL } \\
\text { SAMPLE } \\
\text { TIME } \\
\text { (hr.) }\end{array}$ & LOCATION & $\begin{array}{l}\text { SAMPLE ID/ } \\
\text { LAB ID }\end{array}$ & $\begin{array}{l}\text { SAMPLE } \\
\text { VOLUME } \\
\text { std } m^{3}\end{array}$ & $\begin{array}{l}\text { AVG. DAILY WIND } \\
\text { DIRECTION/SPEED } \\
\text { (degrees @ knots) }\end{array}$ & \multicolumn{2}{|c|}{$\begin{array}{l}\text { PCDD/PCDF CONÇENTRATION } \\
\left(\mathrm{pg} / \mathrm{m}^{3}\right)\end{array}$} & $\mathrm{TEF}^{\mathrm{b}}$ & $T_{E Q}{ }^{C}$ & $\begin{array}{l}\text { BLANK } \\
\text { CONC }^{\mathrm{a}} \\
\left(\mathrm{pg} / \mathrm{m}^{3}\right)\end{array}$ \\
\hline 23-24JAN93 & 23.1 & Hut Point & HPD05/F-899 & 373.7 & 090007 & $\begin{array}{l}\text { HpCDDS (TOTAL) } \\
\text { OCOD } \\
\text { HpCDFs (TOTAL) } \\
1,2,3,4,6,7,8-\text { HpCDF } \\
\text { OCDF } \\
\text { TOTAL PCDD: } \\
\text { TOTAL PCDF: }\end{array}$ & $\begin{array}{l}0.01 \\
0.05 \\
0.25 \\
0.14 \\
0.71 \\
\\
0.06 \\
0.96\end{array}$ & $\begin{array}{l}0.001 \\
0.01 \\
0.001\end{array}$ & $\begin{array}{ll} & 0.00005 \\
& 0.0014 \\
& 0.00071 \\
& \\
\text { TOTAL } & 0.00216\end{array}$ & $\begin{array}{l}0.05 \\
0.10 \\
0.02 \\
0.02 \\
0.03\end{array}$ \\
\hline 23-24JAN93 & 24.4 & Central McMurdo & $M C D 05 / F-902$ & 398.8 & 090007 & $\begin{array}{l}\text { HpCDOS (TOTAL) } \\
1,2,3,4,6,7,8-\mathrm{HpCDO} \\
\text { OCDD } \\
\text { OCDF } \\
\text { TOTAL PCDD: } \\
\text { TOTAL PCDF: }\end{array}$ & $\begin{array}{l}0.07 \\
0.02 \\
0.20 \\
0.01 \\
\\
0.27 \\
0.01 \\
\end{array}$ & $\begin{array}{l}0.01 \\
0.001 \\
0.001\end{array}$ & $\begin{array}{cc}0.0002 \\
0.0002 \\
0.00001 \\
\text { TOTAL } 0.00041\end{array}$ & $\begin{array}{l}0.05 \\
0.03 \\
0.10 \\
0.03\end{array}$ \\
\hline 23-24JAN93 & 23.9 & 8-Site & $\mathrm{TS} 004 / \mathrm{F}-900$ & 387.7 & $090 \bigcirc 07$ & $N D^{e}$ & & & 0 & \\
\hline
\end{tabular}

๘

a. Values reported are corrected for method or $f$ ield blank concentrations.

b. Toxicity Equiva lent Factor (TEF), Reference: U.S. EPA (EPA/625/3-89/016) March 1989

c. Toxicity Equivalent (TEQ) is the equivalent concentration of $2,3,7,8$-TCDD.

d. Method or field blank concentrations used to correct sample results. Two sets of samples and corresponding blanks.

e. Not Detected (ND) indicates compound was not detected or was detected at or be low associated maximum blank concentrations,

f. Not Available or Not Applicable (NA) 
Table. 4 Comparison of Antarctica ambient air concentration of PCDD/PCDF with those of other locations. Antarctic results are in boldface type.

\begin{tabular}{|c|c|c|}
\hline Location/Type & $\begin{array}{c}\text { Total } \\
\text { PCDF } \\
\left(\mathrm{pg} / \mathrm{m}^{3}\right) \\
\end{array}$ & $\begin{array}{c}\text { Total } \\
\text { PCDD } \\
\left(\mathrm{pg} / \mathrm{m}^{3}\right) \\
\end{array}$ \\
\hline Industrial (Hamburg, Germany) ${ }^{a}$ & 15 & 13 \\
\hline Auto-tunnel (Hamburg, Germany) ${ }^{\mathrm{b}}$ & 13 & 16 \\
\hline Industrialc & 10 & 9 \\
\hline Urban $^{d}$ & 8.8 & 8.6 \\
\hline Urban \& industrial (Nordhein-Westfalen, Germany) & 5.5 & 3.2 \\
\hline Urban (Indianapolis, Indiana USA) ${ }^{f}$ & 2.6 & 2.5 \\
\hline Suburban (Hamburg, Germany) ${ }^{g}$ & 0.74 & 1.8 \\
\hline Suburban (B1oomington, Indiana USA) ${ }^{h}$ & 0.63 & 1.2 \\
\hline Suburban ${ }^{i}$ & 0.50 & 1.0 \\
\hline Suburban (Research Triangle Park, North Carolina USA) j & 1.10 & 0.56 \\
\hline Rural (Trout Lake, Wisconsin USA) ${ }^{k}$ & 0.18 & 0.24 \\
\hline Central McMurdo, Antarctica ${ }^{1}$ & 0.56 & 0.61 \\
\hline Hut Point, Antarcticam & 0.19 & 0.06 \\
\hline 8-Site Antarctican & ND & ND \\
\hline Black Island, Antarctica ${ }^{\circ}$ & ND & ND \\
\hline
\end{tabular}

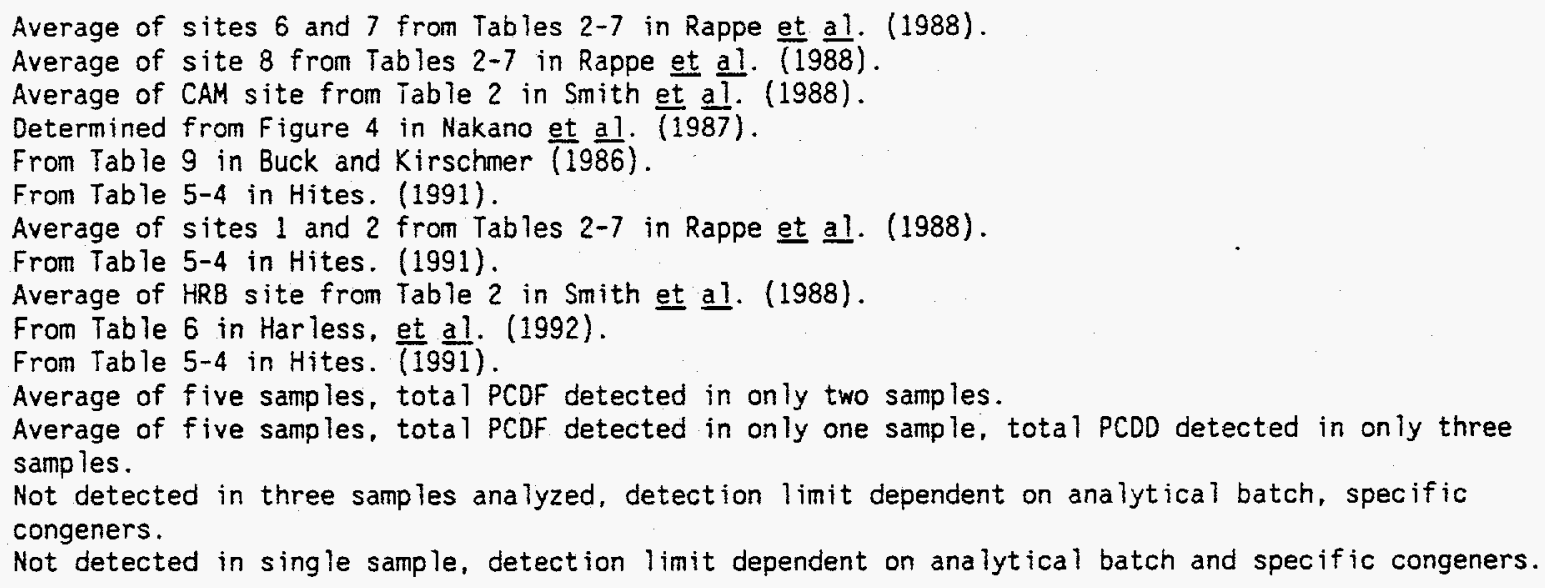

Adopted from Table 5-4, p. 59, in Hites (1991). 
Figure 2. Concentration of Dioxin/Furans in Ambient Air McMurdo, Antarctica 1992-1993 Austral Sum mer

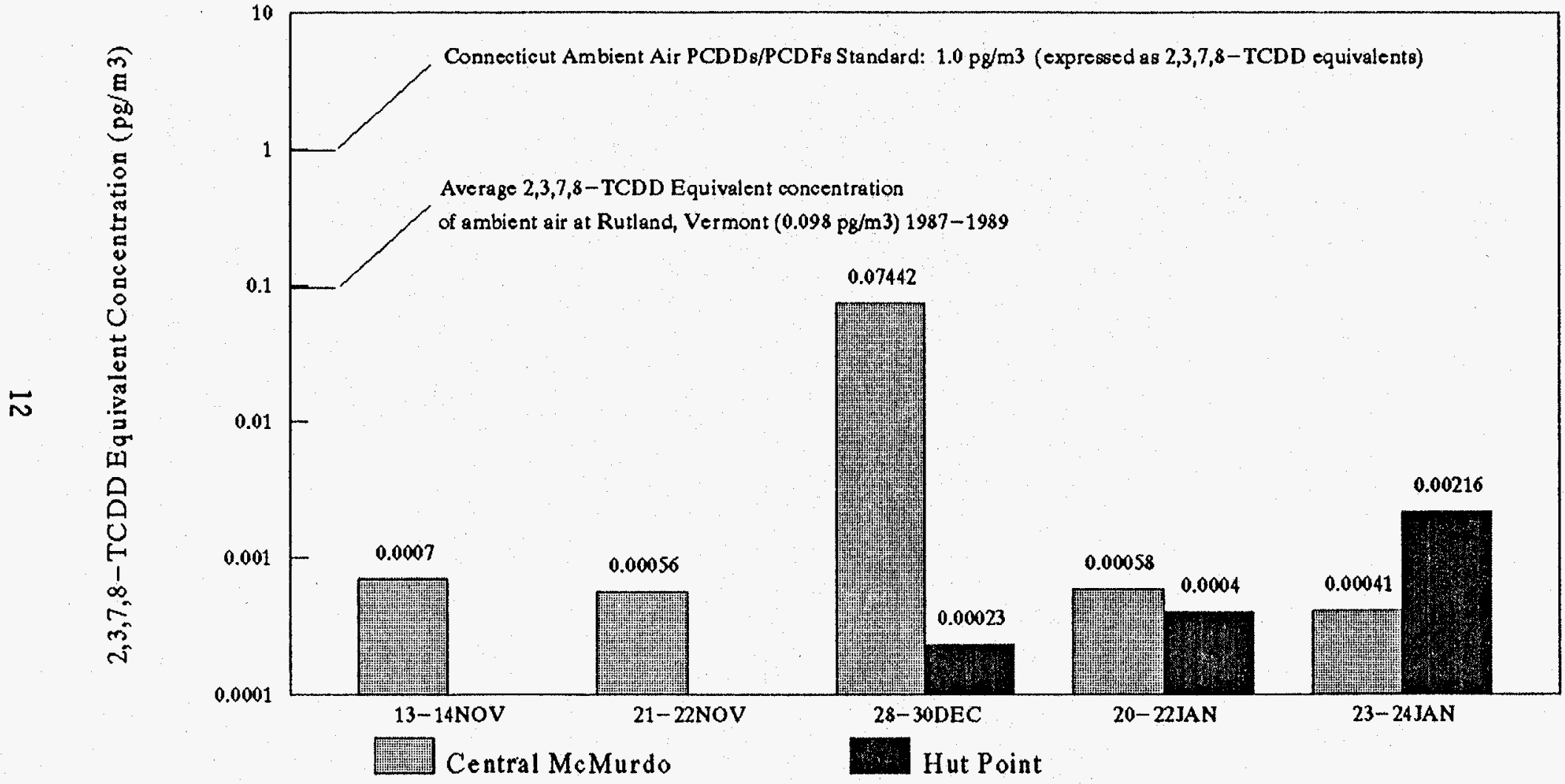

Note: Average 2,3,7,8-TCDD Equival ent concentration for Ruttand, Vermont derived from Table 3-5, of EPA 600-8-91/007 (EPA 1991) 
Figure 3. Ambient Alr Dioxin/Furan Congener Profiles

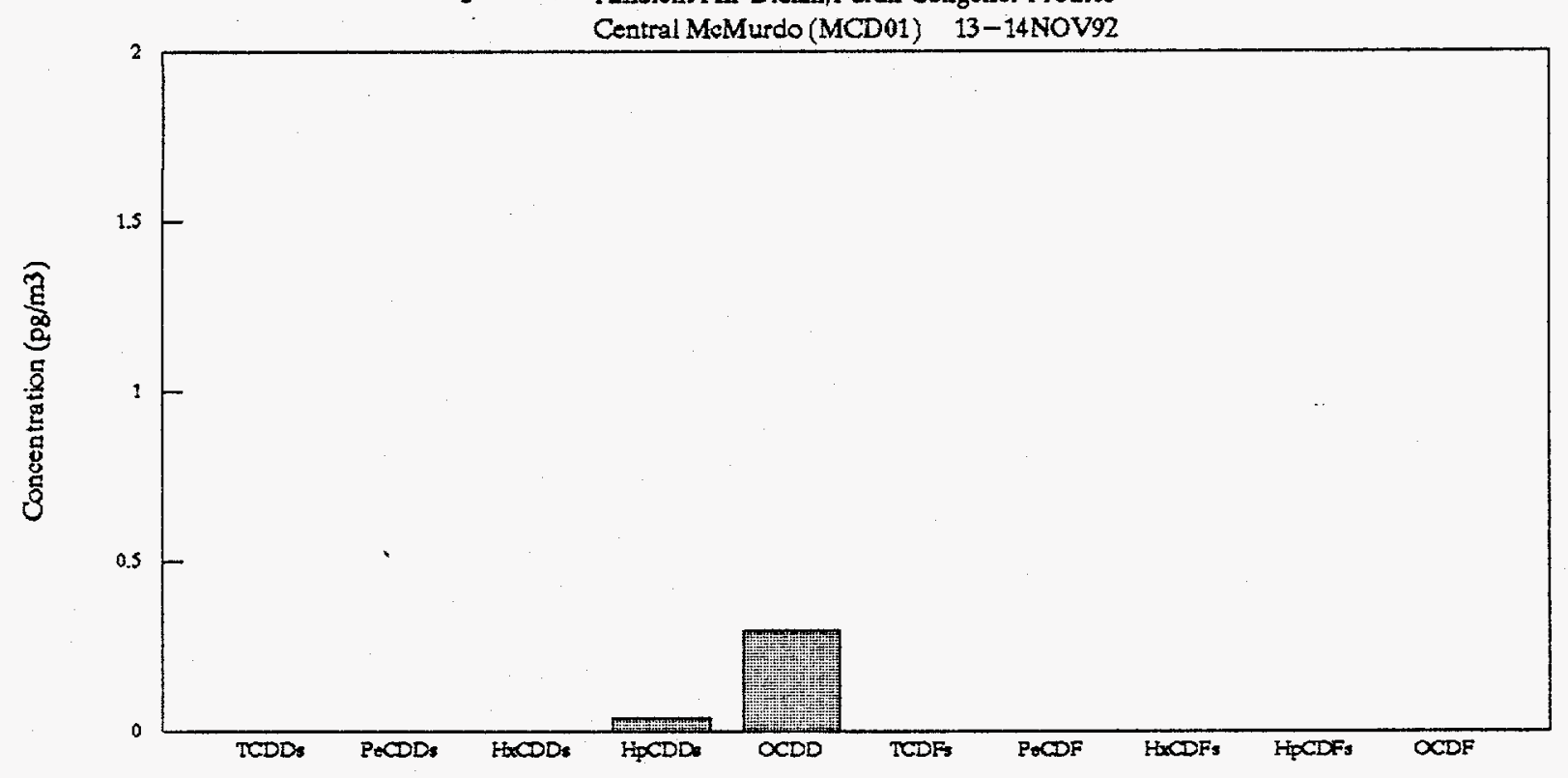

Figure 4. Ambient Air Dioxin/Furan Congener Profiles Central McMurdo (MCD02) 21-22NOV92

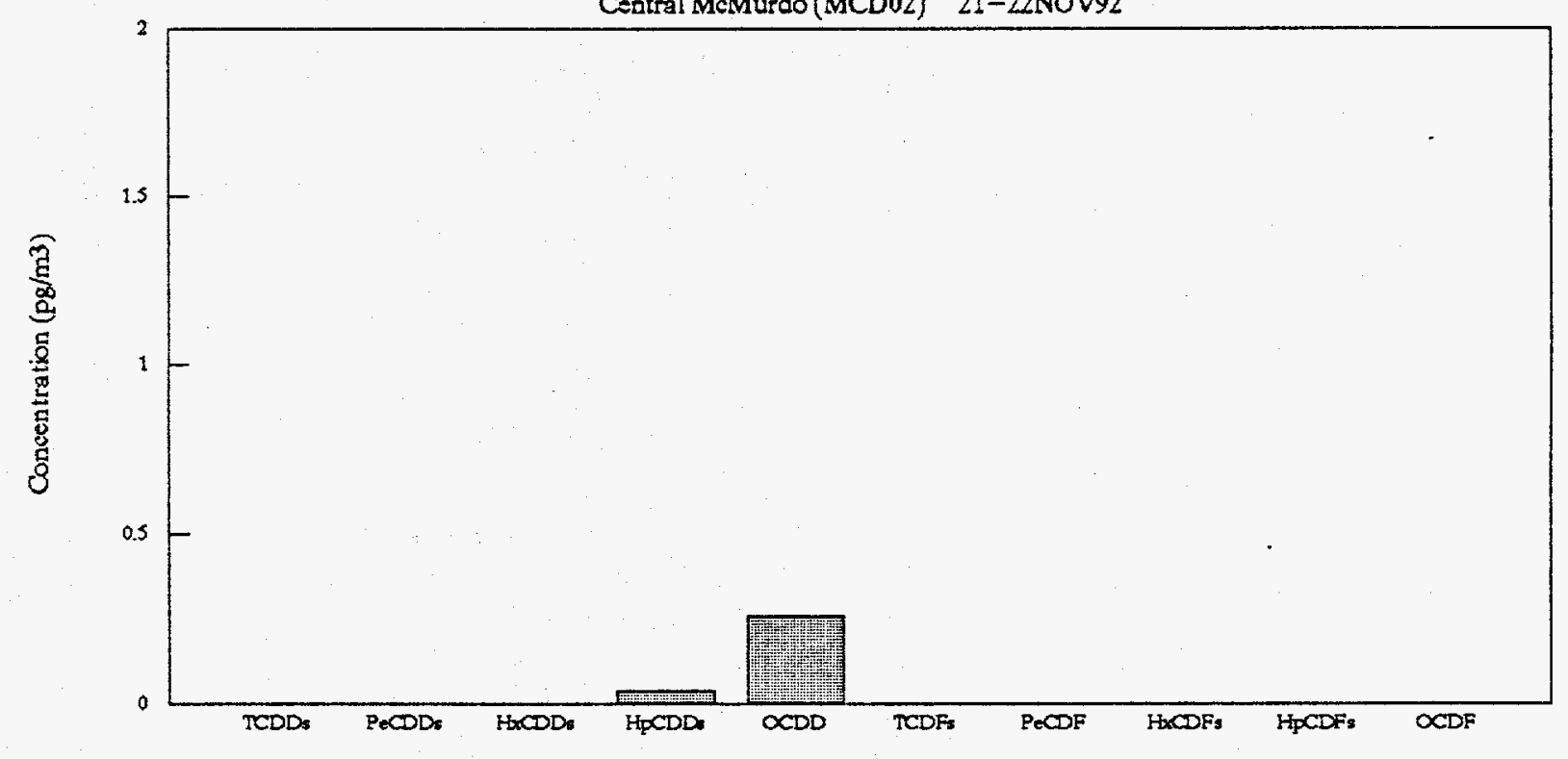


Figure 5. Ambient Air Dioxin/Furan Congener Profiles

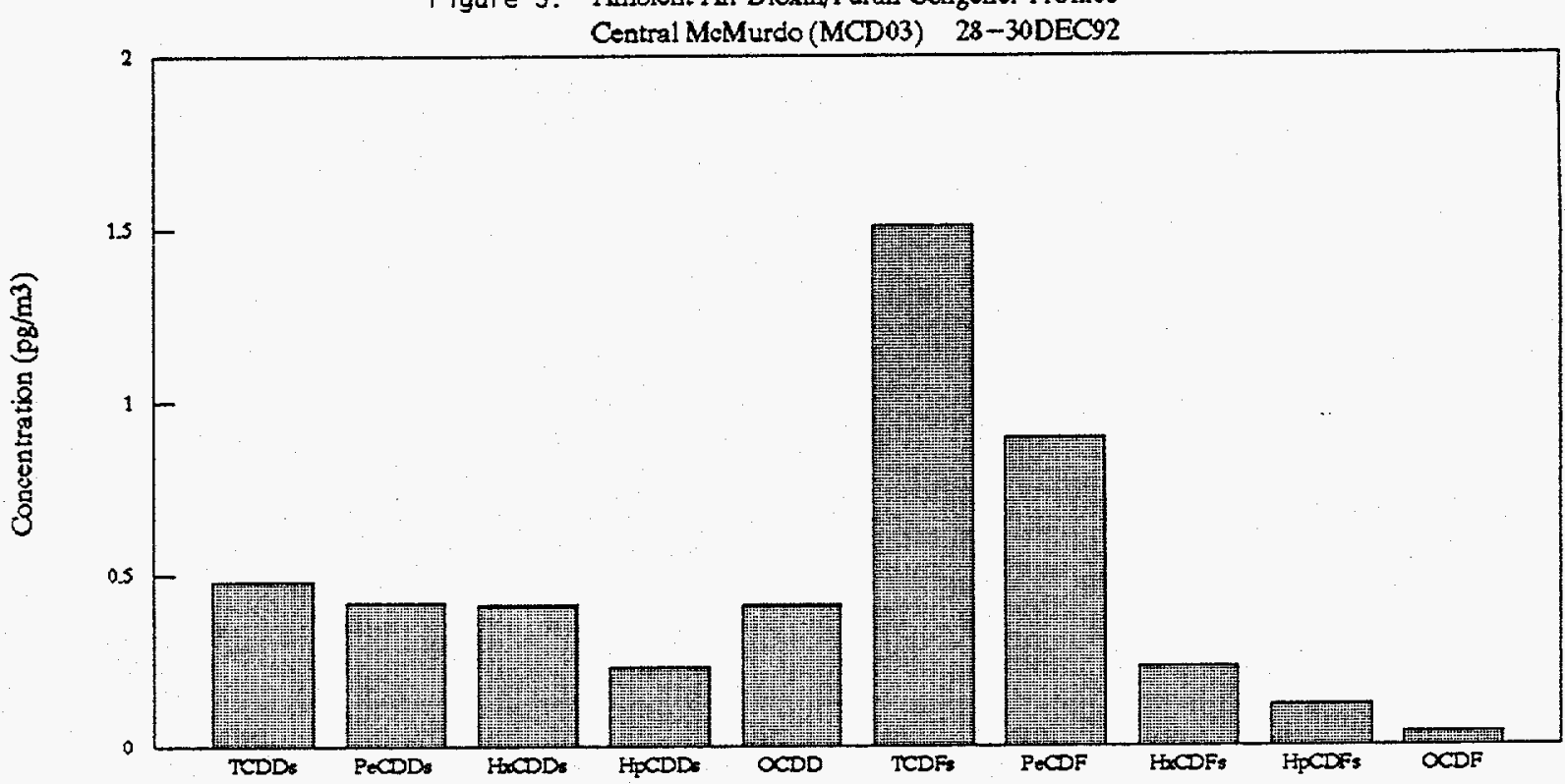

Figure 6. Ambient Alr Dioxin/Furan Congener Profiles

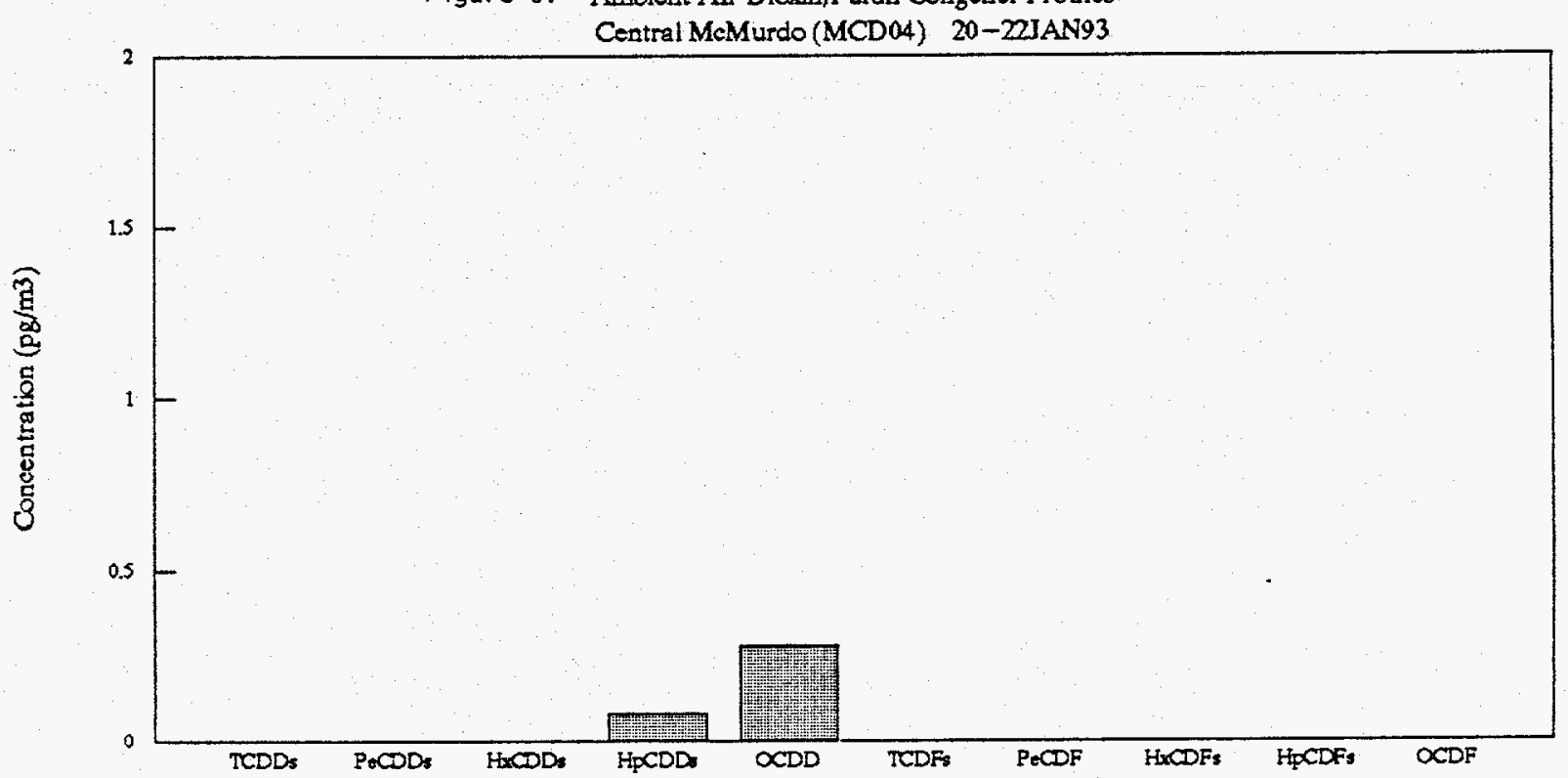


Figure 7. Ambient Alr Dioxin/Furan Congener Profiles

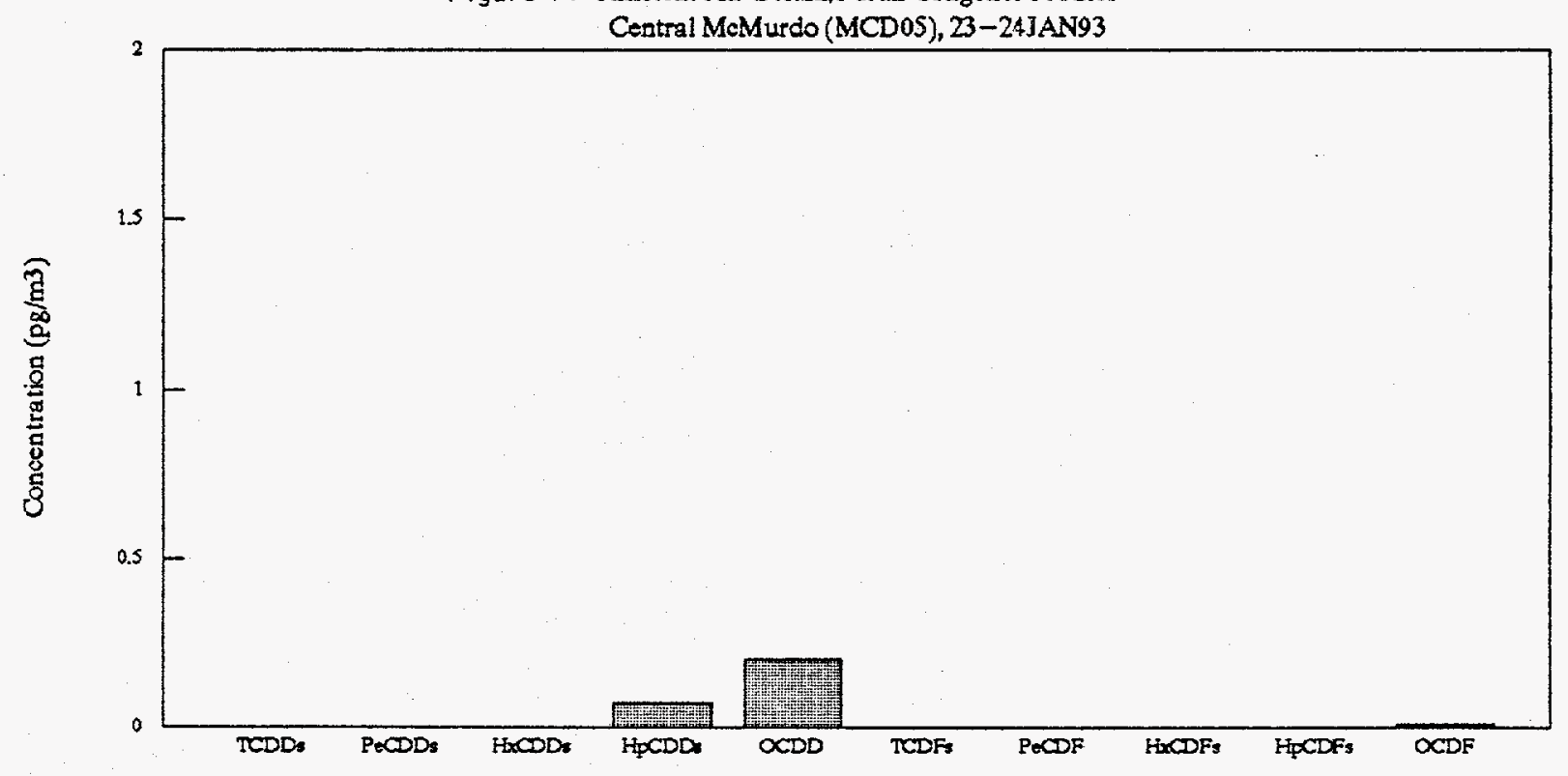


Figure 8. Ambient Alr Dioxin/Furan Congener Profiles

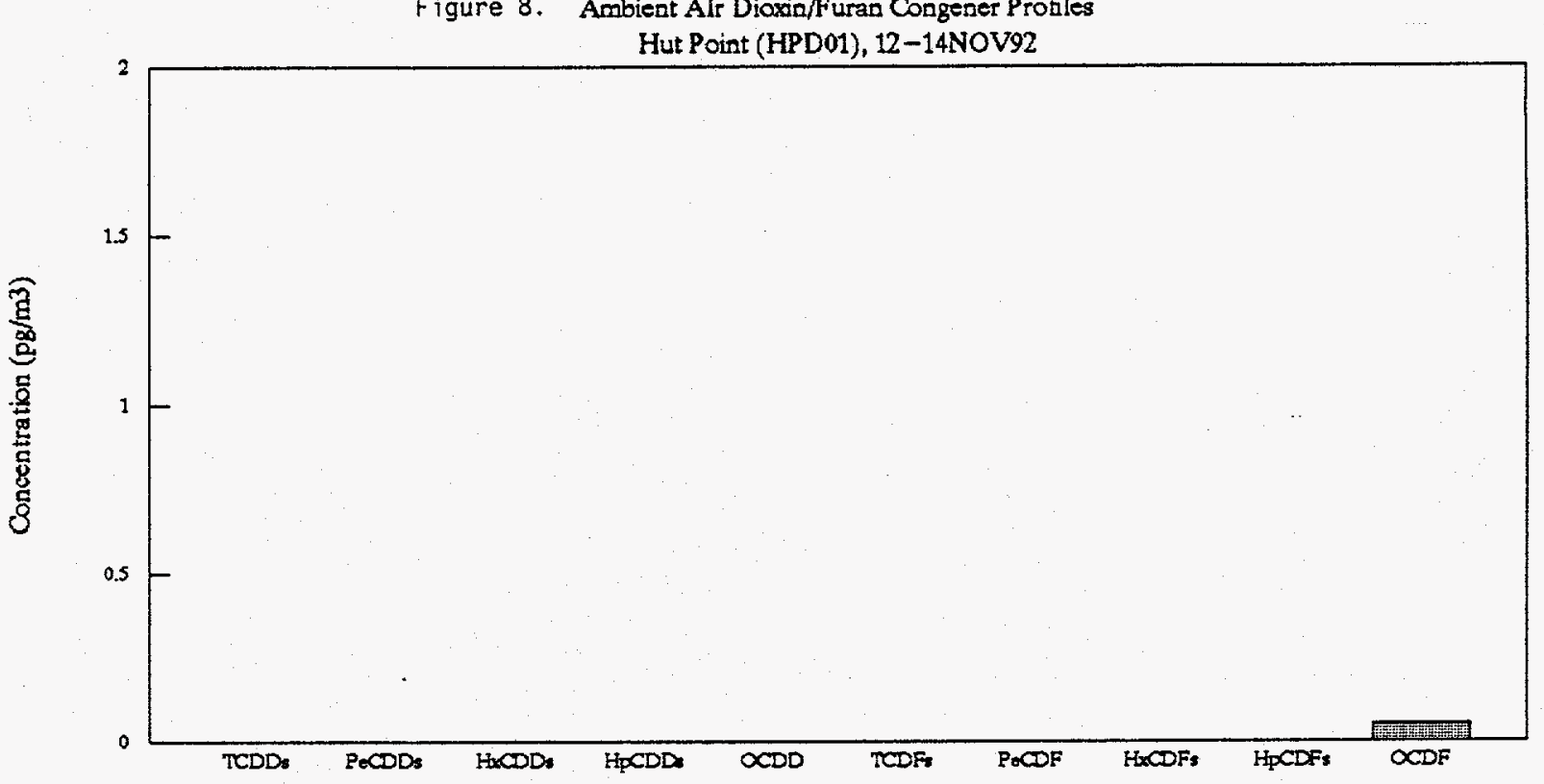

Figure 9. Ambient Alr Dioxin/Furan Congener Profiles. Hut Point (HPD03), 28-30DEC92

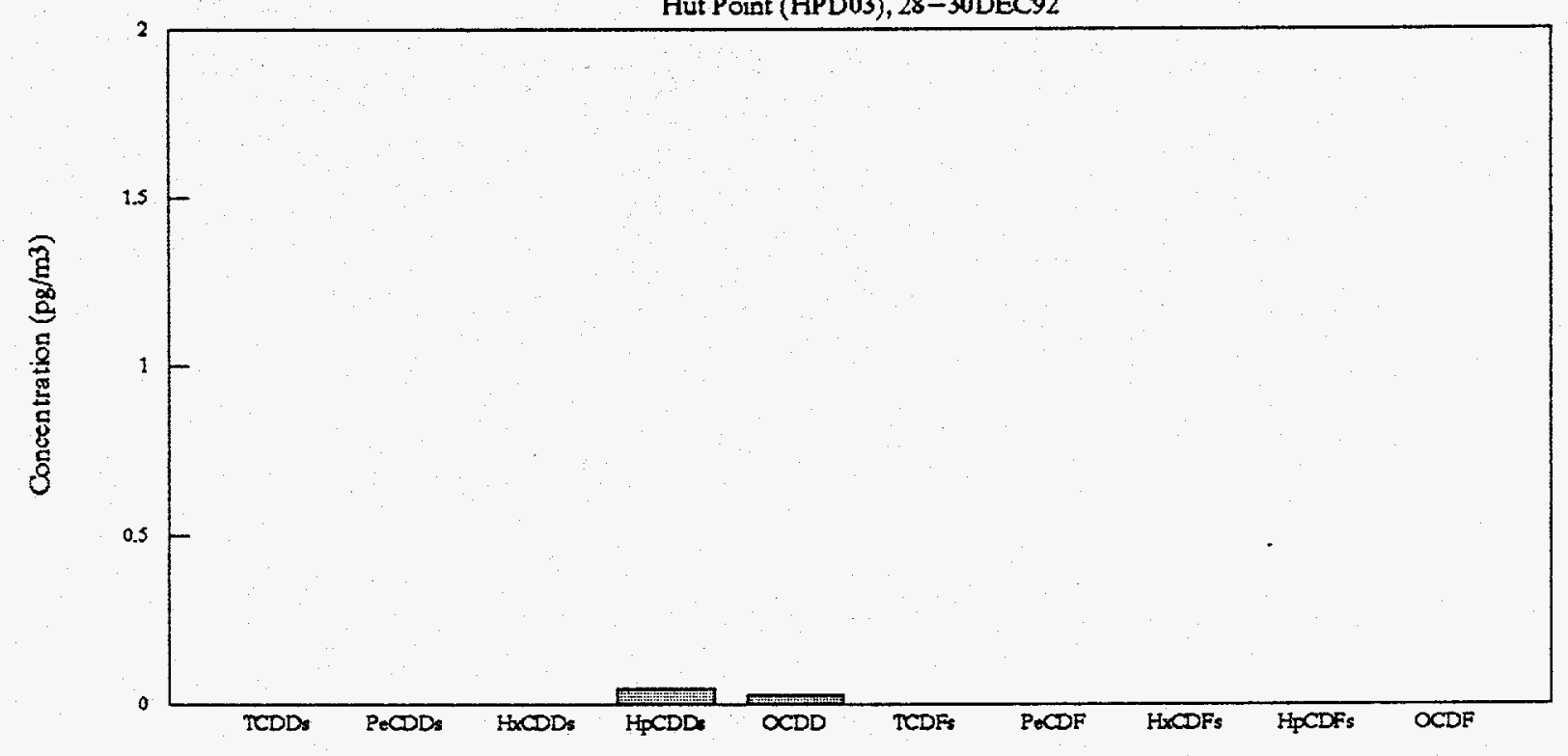


Figure 10. Ambient Air Dioxin/Furan Congener Profiles

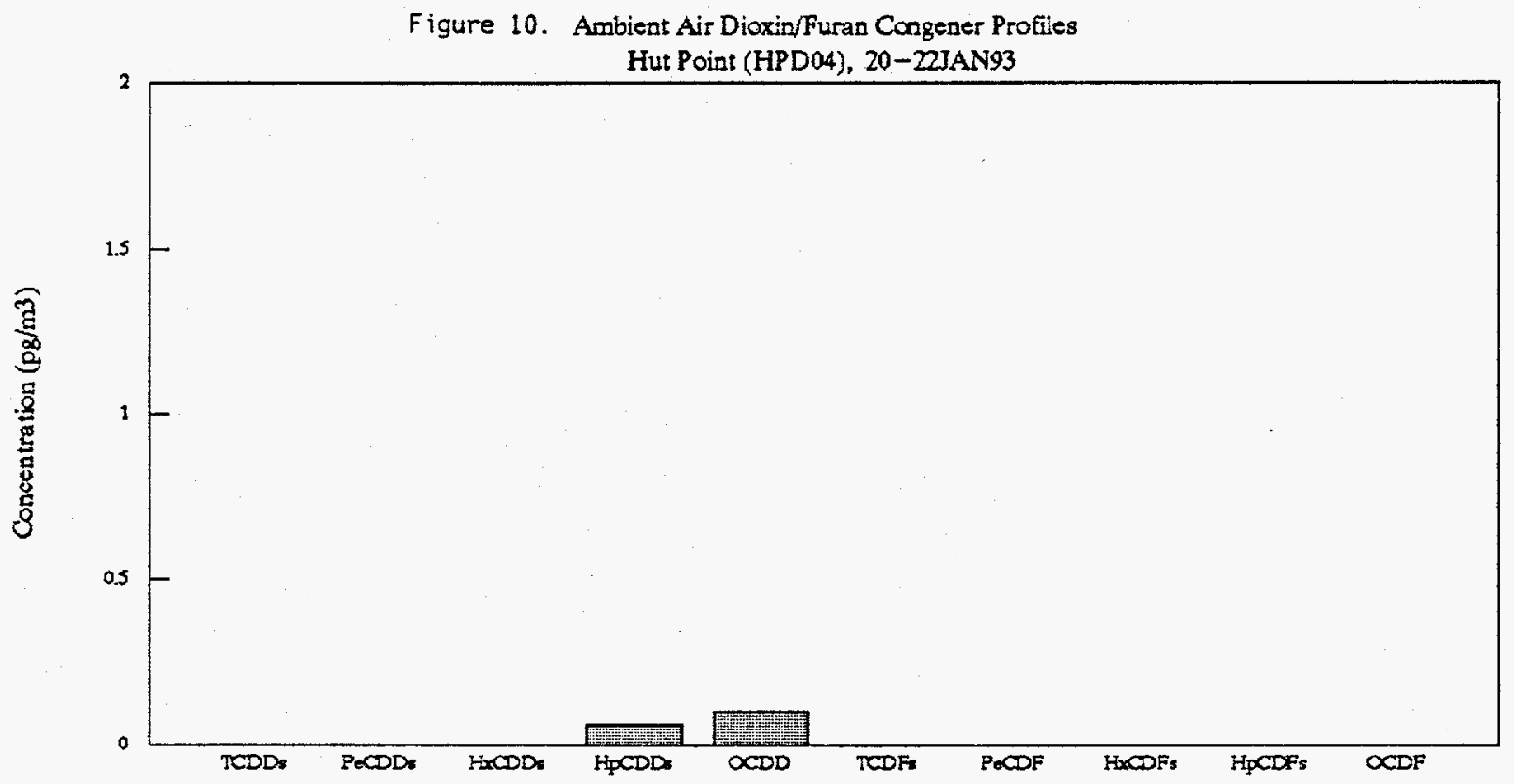

Figure 11. Ambient Alr Dioxin/Furan Congener Profiles

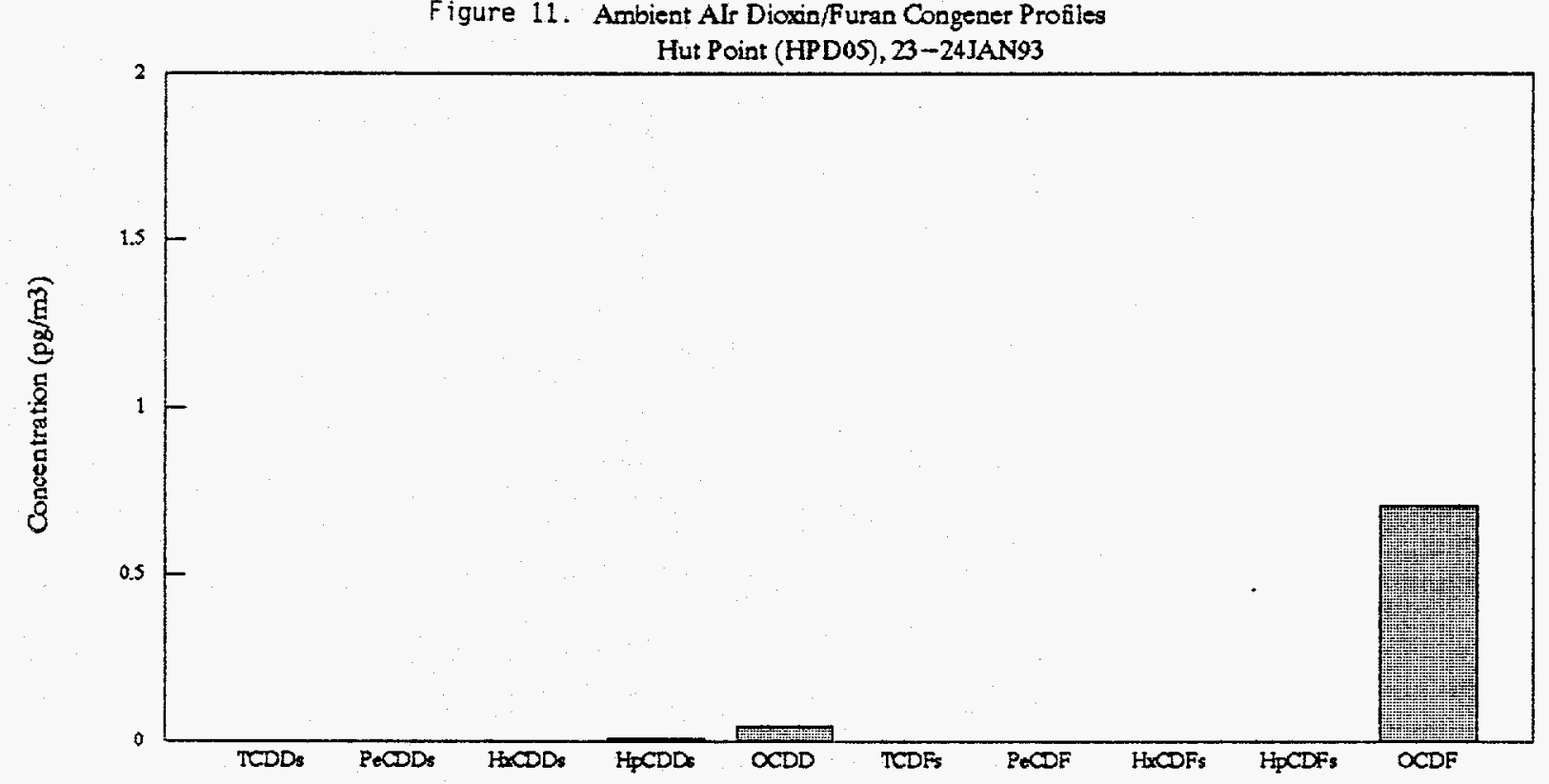


Figure 12. Interim Incinerator Emission PCDD/PCDF Profile

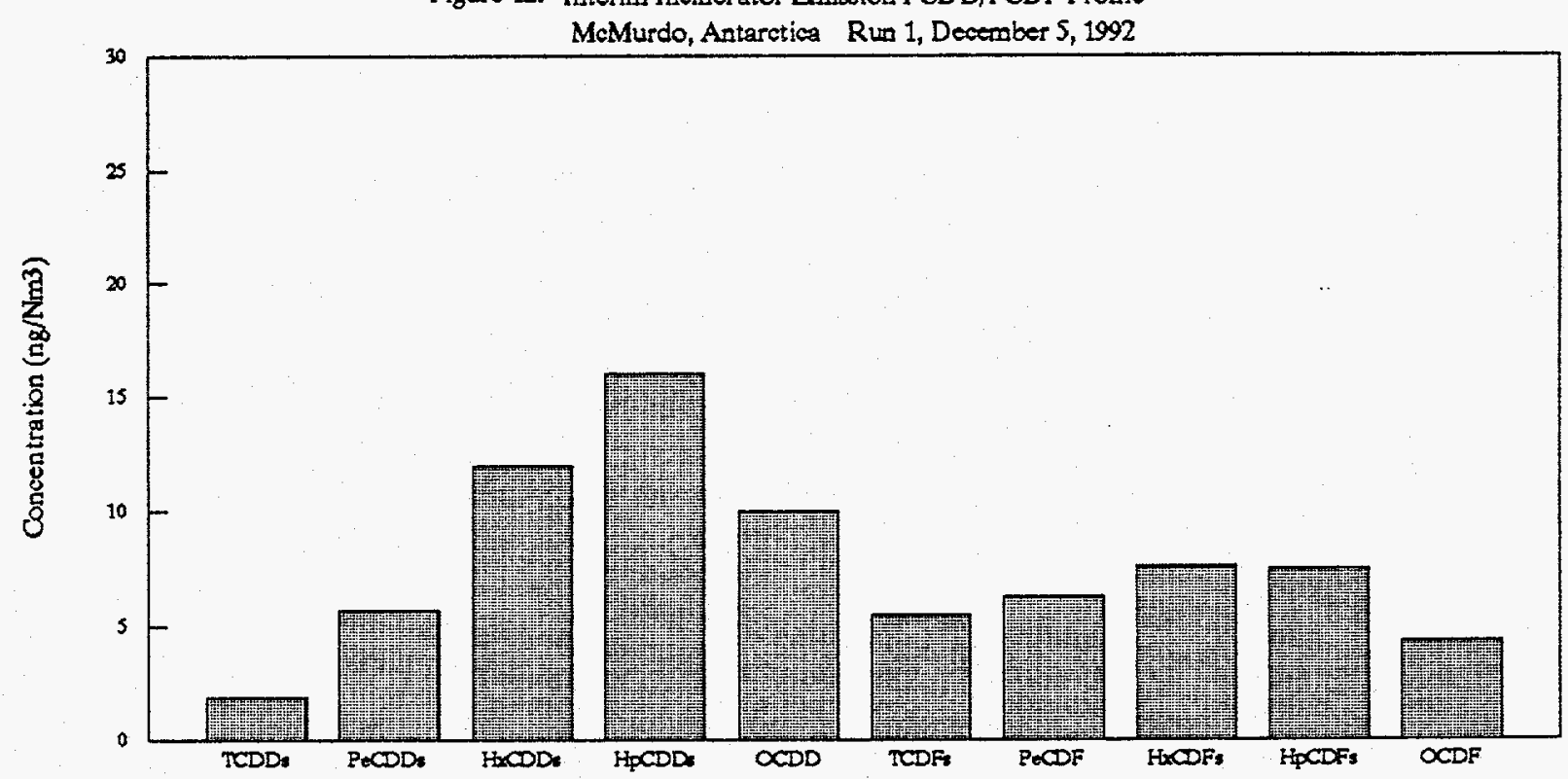

Figure 13. Interim Incinerator Emission PCDD/PCDF Profile

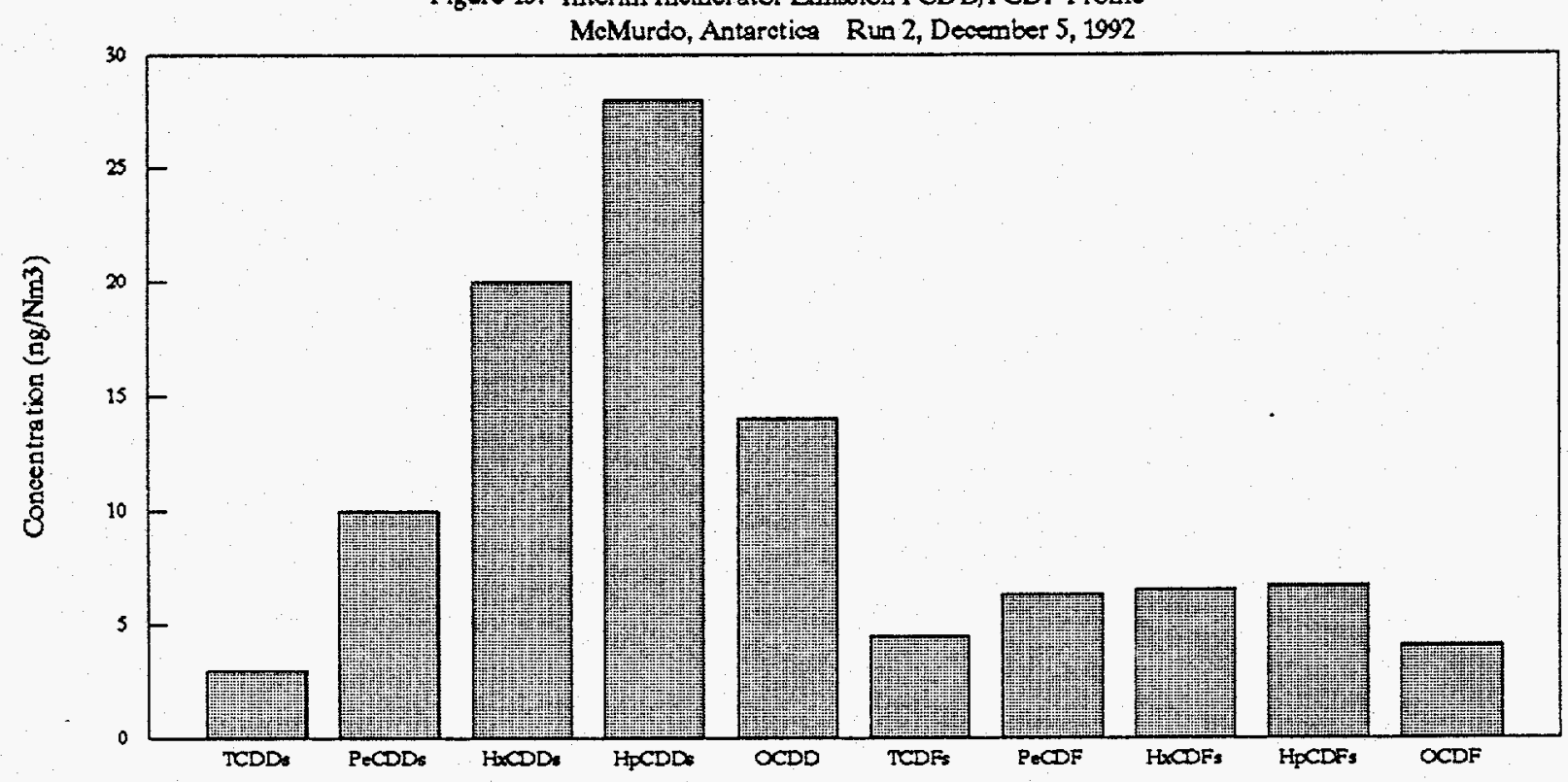


Figure 14. Interim Incinerator Emission PCDD/PCDF Profile

McMurdo, Antaretica Run 3, December 5, 1992

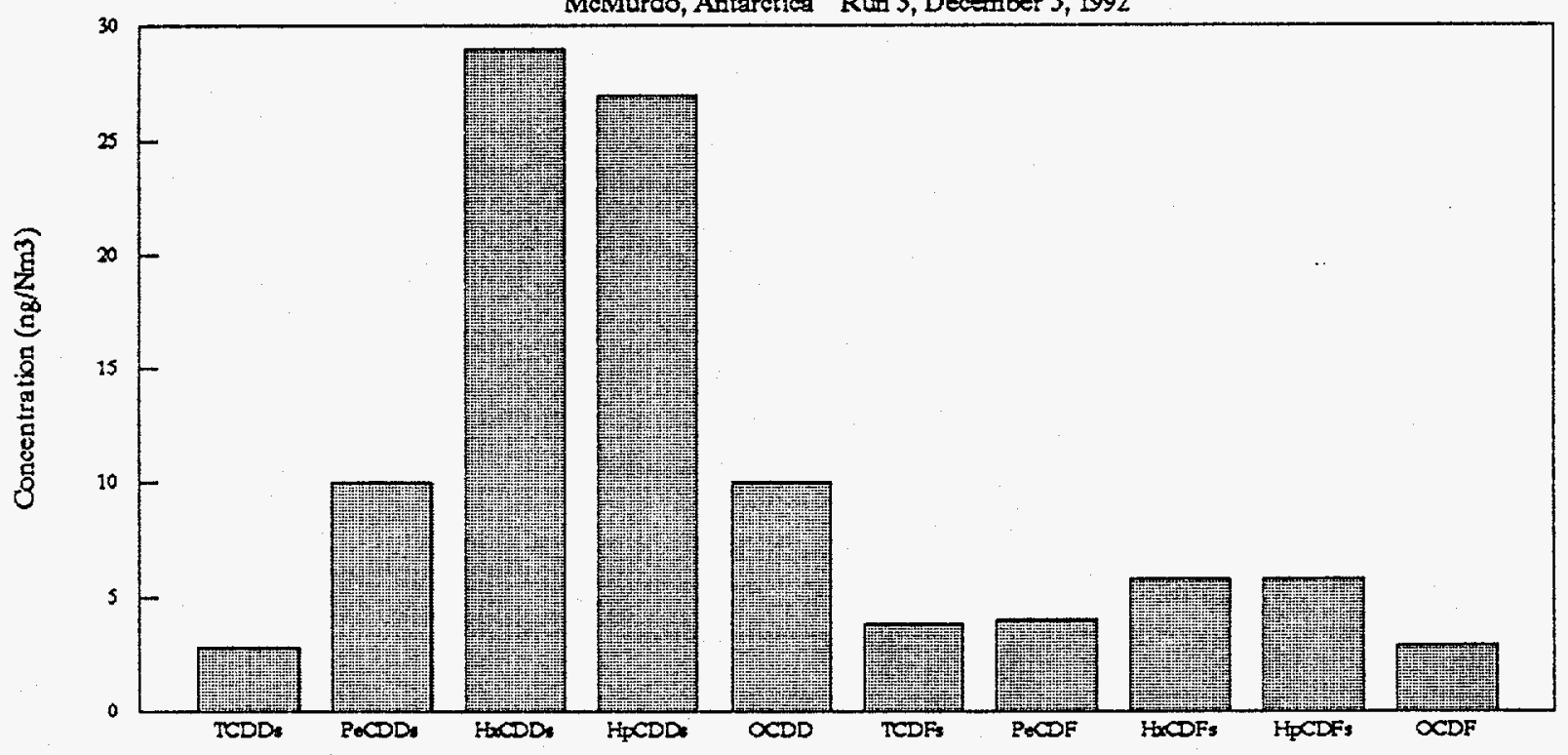


Operating logs indicate the interim incinerator was in operation during most of the sampling period on 28-30DEC92, and the predominant wind direction during the sampling period would have favored the transport of incinerator emissions toward the central McMurdo sampler.

Profiles of PCDD/PCDF congeners measured in the interim incinerator stack gas on 05DEC92 (Figures 12 through 14) were compared to ambient air PCDD/PCDF profiles (Figures 3 through 11) in an attempt to match ambient profiles with profiles from this potential source. The interim incinerator is the only potential McMurdo source that has had its air emissions characterized for PCDDs/PCDFs (Andrews, 1993). No meaningful correlation could be ascertained from this comparison; it is important to note that the three stack tests all occurred on the same day not concurrent with the ambient air sampling. Varied waste input, and changing operating conditions of the incinerator can create different PCDD/PCDF profiles, therefore a reliable conclusion to the comparison of the ambient air profiles and stack emission profiles is not possible, and the exact source of the detected PCDDs/PCDFs cannot be definitively determined from the available data.

Although the total number of samples per location was relatively small, the data do indicate the highest frequency of occurrence and greatest concentration of PCDDS/PCDFs in the ambient air was evident at the "downtown" McMurdo location. The impact of McMurdo operations on ambient air quality at Hut Point in terms of PCDDS/PCDFs was less frequent and at concentrations near the detection limit. PCDD/PCDF concentrations, if present, were below the detection 1 imit at 8-Site, implying that emissions from the New Zealand Scott Base are either not transported to the 8-site, or any emitted PCDDs/PCDFs are diluted to below the detection limit, or there simply are no PCDDs/PCDFs emitted. The remote Black Island sample permitted exceptionally lower detection limits, and the results indicate that the background Antarctic air is still "free" of PCDD/PCDF compounds (not detectable at current method detection limits).

\section{Acknowledgements}

This work was funded by the National Science Foundation Office of Polar Programs through Interagency Agreement \# DPP-9102787 with the Department of Energy Idaho Field office. The author gratefully acknowledges the project direction and technical support provided by Dr. Sydney Draggan; Dr. Jane Dionne, Alan Crockett, and Dr. Robert Harless; the logistics, construction, and Taboratory support provided by Antarctic Support Associates personnel Dennis Tupick, John and Laurie Sherve, and Dr. Steve Kottmeier; and sample collection assistance provided by Jarvis Belinne. The author thanks Dr. Aubry DuPuy and Danny McDaniel at the U.S. EPA Environmental Chemistry Laboratory at the Stennis Space Center, Mississippi, for their support in sample cartridge preparation and sample extraction, and Dr. Robert Lewis and Dr. Robert Harless of the U.S. EPA Atmospheric Research and Exposure Assessment Laboratory at Research Triangle Park, North Carolina, for sample analys is and analytical data reporting. 


\section{References}

Andrews, Caro1. 1993. "Report on December 1992 McMurdo Station Power Plant and Interim Incinerator Stack Testing". Prepared by Antarctic Support Associates for the National Science Foundation. (unpublished)

Buck, M. and Kirschmer, P. 1986. Immissionsmessungen polychlorierter dibenzop-dioxine und dibenzofurane in Nordheim-Westfalen. LIS-Berichte Nr62 Dp4300, Essen BRD.

Code of Federal Regulations, 40CFR58, Appendix D, "Network Design for State and Local Air Monitoring Stations (SLAMS) and National Air Monitoring Stations (NAMS)," July 1989.

Harless, R.L., et al, 1992. Evaluation of a Sampling and Analys is Method for Determination of Polyhalogenated Dibenzo-p-Dioxins and Dibenzofurans in Ambient Air. Chemosphere, Vol.25, Nos. 7-10, pp. 1317-1322, Oct.-Nov., 1992.

Hites, Ronald A., 1991. Atmospheric Transport and Deposition of Polychlorinated Dibenzo-p-Dioxins and Dibenzofurans. Technical report prepared for U.S. Environmental Protection Agency, Research Triangle Park, NC. EPA/600/3-91/002, PB91-144667. January 1991.

Lugar, Robert M., 1992. FY-1993 Ambient Air Monitoring Plan for McMurdo Station, Antarctica. Prepared for National Science Foundation Division of Polar Programs. EG\&G Idaho, Idaho Falls, ID 83415-1406. September 1992. (unpubl ished)

Nakano, T., Tsuji, M., and Okuno, T. 1987. Level of Chlorinated Organic Compounds in the Atmosphere. Chemosphere 16, 1781-1786.

National Science Foundation, 1989. Implementation of the National Science Foundation's Strategy for Compliance with Environmental Law in Antarctica. National Science Foundation, Washington, D.C. 19 pp. 1989.

National Science Foundation, 1991. Supplemental Environmental Impact Statement for the United States Antarctic Program. National Science Foundation, Washington, D.C. October 1991.

Pearson, C.V., 1991. Technology Assessment: Evaluation and Design of a High Temperature Incinerator for Treatment of Solid Wastes at McMurdo Station, Ross Island, Antarctica. Part II: Reference System Description for the Interim Incinerator Facility. Argonne National Laboratory, Argonne, IL. June 1991. (unpublished)

Rappe, C., Kjeller, L.-0., Bruckmann, P., and Hackhe, K.-H.. 1988. Identification and Quantification of PCDDs and PCDFs in Urban Air. Chemosphere $17,3-20$. 


\section{References - continued}

Smith, R.M., O'Keefe, P.W., Hilker, D.R., Aldous, K.M., Mo, S.H., and Stelle, R.M. 1988. Ambient Air and Incinerator Testing for Chlorinated Dibenzofurans and Dioxins by Low Resolution Mass Spectrometry. Chemosphere.

United States Environmental Protection Agency, 1977. Quality Assurance Handbook for Air Pollution Measurement Systems, Volume II - Ambient Air Specific Methods. Research Triangle Park, NC. EPA-600/4-77-027a, May 1977.

United States Environmental Protection Agency, 1986. Supplement to EPA/600/484/041: Compendium of Methods for the Determination of Toxic Organic Compounds in Ambient Air. Research Triangle Park, NC. EPA/600/4-87-006, September 1986.

United States Environmental Protection Agency, 1991. Feasibility of Environmental Monitoring and Exposure Assessment for a Municipal Waste Combustor: Rutland, Vermont Pilot Study. Cincinnati, Ohio. EPA/600/891/007, PB91-181917. January 1991. 


\section{APPENDIX A}

Raw PCDD/PCDF Analytical Results 


\author{
UNITED STATES ENVIRONMENTAL PROTECTION AGENCY \\ ATMOSPHERIC RESEARCH AND EXPOSURE ASSESSMENT LABORATORY \\ RESEARCH TRIANGLE PARK \\ NORTH CAROLINA 27711
}

April 6, 1993

Dr. Sidney Draggan

Division of Polar Programs

office of the Environment

National Science Foundation

$1800 \mathrm{G}$ Street, NW

washington, DC 20550

Dear Dr. Draggan:

The analysis of ambient air samples from the Antarctica for polychlorinated dibenzo-p-dioxins (PCDDs) and polychlorinated dibenzofurans (PCDFS) is now complete. Background information is summarized. Polyurethane foam (PUF) plugs provided by Robert Lugar, Idaho National Engineering Laboratory (INEL) were subjected to an extraction and cleanup procedure at the US Environmental Protection Agency, Environmental Chemistry Laboratory (US EPA-ECL), Stennis Space center, Mississippi. The seventeen PUFs were then fortified with $800 \mathrm{pg}$ each of ${ }^{13} \mathrm{C}_{12}-1,2,3,4-\mathrm{TCDD}$ and shipped to Antarctica for sampling purposes. Ambient air sampling in Antarctica was conducted by Robert Lugar and his colleaques from INEL. After sampling, the PUFs and filters were shipped back to the US EPA-ECL for sample preparation. The extracts from the sample preparations were then shipped to this laboratory for analysis. High resolution gas chromatography-high resolution mass spectrometry (HRGC-HRMS) analyses were performed on the extracts using a Finnegan MAT 90 HRGC-HRMS system. The analytical procedures used were similar to EDA Method 8290 and 1613.

Analytical results generated for the two shipments of samples from Antarctica are shown in Tables 1 through 5. The QA/QC sample results shown in Table 2 are used in evaluation of results for test samples shown in Table 1, the first shipment. One test sample in this set was lost during extraction. The QA/QC sample results in Table 4 are used in evaluation of test sample results shown in Tables 3 and 5 . These results for the test samples and $Q A / Q C$ samples satisfies our data quality requirements for efficiency, accuracy, identification criteria, etc. The trace levels of PCDDs and PCDFs detected in the method blanks and field blanks are similar to those always detected (method background levels) and do not distract from the significance of results for the test samples. 
In general, the extracts were very clean and the results indicate the ambient air in Antarctica is much cleaner than the ambient air in the USA, as it should be. However, the input of trace levels of PCDDs and PCDFs to the atmosphere is apparent in several of the samples, F-879, F-882, F-899 and especially F-901. The profiles of PCDDs and PCDFs and the isomer patterns in sample F-901 clearly indicate they came from a combustion source(s). Three of these positive samples are from the same site, MCD. The results are very interesting. I suggest the sampling, sample sites and analytical results be discussed in detail by the participants.

Please call me at (919) 541-2248 if you have any questions.

$$
\text { SincereIy, }
$$

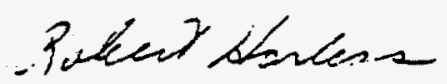

Robert Harless

Research Chemist

Enclosures

CC: W. MCClenny (MD-44)

R. Lewis $(M D-44)$

A. Dupuy (ECL-MS)

D. MCDaniel (ECL-MS)

Robert Iugar (INEL) 
TABLE 1. Analytical Results for PCDDs and PCDFs in Ambient Air Samples from Antartica

\begin{tabular}{|c|c|c|c|c|c|}
\hline IDENTIFICATION & $F-878$ & $F-879$ & $F-880$ & $F-881$ & F-882 \\
\hline \multicolumn{6}{|c|}{ PS-1 AIR SAUPLER EFFICIENCY (\% RECOVERY) } \\
\hline${ }^{13} C_{12}-1,2,3,4 T C D D$ & 106 & 97 & 95 & 96 & 99 \\
\hline \multicolumn{6}{|c|}{ METHOD EFFICIENCY (\% RECOVERY) } \\
\hline${ }^{33} \mathrm{C}_{12}-2,3,7,8-\mathrm{TCDF}$ & 86 & 82 & 81 & 83 & 87 \\
\hline${ }^{13} C_{12}-2,3,7,8-T C D D$ & 79 & 90 & 87 & 85 & 90 \\
\hline${ }^{13} \mathrm{C}_{12}-1,2,3,7,8-\mathrm{PeCDF}$ & 91 & 86 & 81 & 82 & 87 \\
\hline${ }^{13} \mathrm{C}_{12}-1,2,3,7,8-\mathrm{PeCDD}$ & 88 & 86 & 78 & 81 & 86 \\
\hline${ }^{13} \mathrm{C}_{12}-1,2,3,4,7,8-\mathrm{H} \times \mathrm{CDF}$ & 89 & 83 & 80 & 84 & 87 \\
\hline${ }^{13} \mathrm{C}_{12},-1,2,3,6,7,8 \mathrm{H} \times \mathrm{CDD}$ & 87 & 83 & 79 & 80 & 86 \\
\hline${ }^{13} C_{12}-1,2,3,4,6,7,8-\mathrm{HPCDF}$ & 79 & 76 & 69 & 66 & $\pi$ \\
\hline${ }^{13} \mathrm{C}_{12}-1,2,3,4,6.7,8-\mathrm{HpCDD}$ & 81 & 82 & 75 & 75 & 84 \\
\hline${ }^{13} \mathrm{C}_{12}-\mathrm{OCDD}$ & 73 & 82 & 70 & 73 & 74 \\
\hline \multicolumn{6}{|c|}{ CONCENTRATIONS DETECTED OR MLD $\left(\mathrm{pg} / \mathrm{m}^{3}\right)$} \\
\hline (TOTAL) & $\mathrm{ND}(0.01)$ & $\mathrm{ND}(0.04)$ & $\mathrm{ND}(0.003)$ & $\mathrm{ND}(0.006)$ & $\mathrm{ND}(0.009)$ \\
\hline $2,3,7,8-T C D D$ & $\mathrm{ND}(0.01)$ & $\mathrm{ND}(0.04)$ & $\mathrm{ND}(0.003)$ & $\mathrm{ND}(0.006)$ & $\mathrm{ND}(0.009)$ \\
\hline (TOTAL) & $\mathrm{ND}(0.01)$ & $\mathrm{ND}(0.01)$ & $\mathrm{ND}(0.002)$ & $\mathrm{ND}(0.01)$ & $\mathrm{ND}(0.01)$ \\
\hline $1,2,3,7,8-\mathrm{PeCDD}$ & $\mathrm{ND}(0.01)$ & $\mathrm{ND}(0.01)$ & $\mathrm{ND}(0.002)$ & $\mathrm{ND}(0.01)$ & $\mathrm{ND}(0.004)$ \\
\hline (TOTAL) & $\mathrm{ND}(0.06)$ & $\mathrm{ND}(0.08)$ & 0.008 & 0.03 & 0.07 \\
\hline $1,2,3,4,7,8-\mathrm{H} \times C D D$ & $\mathrm{ND}(0.03)$ & $\mathrm{ND}(0.02)$ & $\mathrm{ND}(0.002)$ & $\mathrm{ND}(0.005)$ & $\mathrm{ND}(0.01)$ \\
\hline $1,2,3,6,7,8-\mathrm{H} \times \mathrm{CDD}$ & $\mathrm{ND}(0.03)$ & $\mathrm{ND}(0.02)$ & $\mathrm{ND}(0.002)$ & $\mathrm{ND}(0.005)$ & $\mathrm{ND}(0.01)$ \\
\hline 1,2.3.7.8.9-HxCDD & $\mathrm{ND}(0.03)$ & $\mathrm{ND}(0.02)$ & $\mathrm{ND}(0.002)$ & $\mathrm{ND}(0.005)$ & $\mathrm{ND}(0.01)$ \\
\hline (TOTAL) & 0.09 & 0.16 & 0.015 & 0.07 & 0.16 \\
\hline $1,2,3,4.6,7,8-\mathrm{HPCDD}_{\mathrm{P}}$ & 0.04 & 0.10 & 0.008 & 0.03 & 0.09 \\
\hline$O C D D$ & 0.23 & 0.64 & 0.046 & 0.20 & 0.60 \\
\hline (TOTAL) & $\mathrm{ND}(0.02)$ & $\mathrm{ND}(0.02)$ & $\mathrm{ND}(0.004)$ & $\mathrm{ND}(0.009)$ & $\mathrm{ND}(0.01)$ \\
\hline $2,3,7,8-\mathrm{TCDF}$ & $\mathrm{ND}(0.02)$ & $\mathrm{ND}(0.02)$ & $\mathrm{ND}(0.004)$ & $\mathrm{ND}(0.009)$ & $N D(0.01)$ \\
\hline (TOTAL) & $\mathrm{ND}(0.01)$ & $\mathrm{ND}(0.007)$ & $N D(0.002)$ & $\mathrm{ND}(0.01)$ & $\mathrm{ND}(0.01)$ \\
\hline 1,2,3,7,8-PeCDF & $\mathrm{ND}(0.01)$ & $\mathrm{ND}(0.007)$ & $N D(0.002)$ & $\mathrm{ND}(0.01)$ & $\mathrm{ND}(0.01)$ \\
\hline $2,3,4,7,8-\mathrm{PeCDF}$ & $\mathrm{ND}(0.01)$ & $\mathrm{ND}(0.007)$ & $\mathrm{ND}(0.002)$ & $\mathrm{ND}(0.01)$ & $\operatorname{ND}(0.01)$ \\
\hline (TOTAL) & $\mathrm{ND}(0.02)$ & $\mathrm{ND}(0.01)$ & $\mathrm{ND}(0.003)$ & $\mathrm{ND}(0.02)$ & $\mathrm{ND}(0.01)$ \\
\hline $1,2,3,4,7,8-\mathrm{HxCDF}$ & $\mathrm{ND}(0.02)$ & $\mathrm{ND}(0.01)$ & $\mathrm{ND}(0.003)$ & $\mathrm{ND}(0.008)$ & $\mathrm{ND}(0.01)$ \\
\hline $1,2,3,6,7,8-\mathrm{HxCDF}$ & $\mathrm{ND}(0.02)$ & $\mathrm{ND}(0.01)$ & $\mathrm{ND}(0.003)$ & $\mathrm{ND}(0.008)$ & $\mathrm{ND}(0.01)$ \\
\hline $12,3,7,8,9-\mathrm{H} \times \mathrm{CDF}$ & $\mathrm{ND}(0.02)$ & $\mathrm{ND}(0.01)$ & $\mathrm{ND}(0.003)$ & $\mathrm{ND}(0.008)$ & $\mathrm{ND}(0.01)$ \\
\hline $2,3,4,6,7,8-\mathrm{HxCDF}$ & $\mathrm{ND}(0.02)$ & $\mathrm{ND}(0.01)$ & $\mathrm{ND}(0 . \infty 03)$ & $\mathrm{ND}(0.008)$ & $\mathrm{ND}(0.01)$ \\
\hline (TOTAL) & 0.05 & 0.04 & 0.004 & 0.03 & 0.05 \\
\hline $1,23,4,6,7,8-\mathrm{HpCDF}$ & 0.03 & 0.02 & 0.003 & 0.02 & 0.03 \\
\hline $123,4,7,8,9-\mathrm{HpCDF}$ & $\mathrm{ND}(0.006)$ & $\mathrm{ND}(0.02)$ & $\mathrm{ND}(0.008)$ & $\mathrm{ND}(0.008)$ & $\mathrm{ND}(0.002)$ \\
\hline$O C D F$ & 0.10 & 0.04 & 0.005 & 0.03 & 0.04 \\
\hline
\end{tabular}

ND = Not detected at specified minimum limit of detection (MLD).

TOTAL = All congeners, including the 2,3.7,8-substituled congeners.

- F-878 = HPD01, Antarctica air, 671.5 m $\mathrm{m}^{3} \quad \mathrm{~F} 881=\mathrm{HPDO2}$, Antarctica air, $744.3 \mathrm{~m}^{3}$

F-879 = MCD01. Antarctica air, $391.8 \mathrm{~m}^{3}, \quad$ F-882 $=M C D 02$, Antartica air, $778.4 \mathrm{~m}^{3}$

F-880 = BID01, Antarctica air, $2586 \mathrm{~m}^{3}$. 
TABLE 2. Analytical Results for PCDDs and PCDFs in Ambient Air Sampies from Antartrica (QA/QC Samples)

\begin{tabular}{|c|c|c|c|}
\hline IDENTIFICATION: & $F-883$ & F-892 & $F-893$ \\
\hline \multicolumn{4}{|c|}{ PS-1 AIR SAMPLER EFFICIEVCY (\% RECOVERY) } \\
\hline${ }^{13} \mathrm{C}_{12}-1,2,3,4-\mathrm{TCDD}$ & 106 & 89 & 96 \\
\hline \multicolumn{4}{|c|}{ METHOD EFFICIENCY (\% RECOVERY) } \\
\hline${ }^{13} \mathrm{C}_{12}-2,3,7,8-\mathrm{TCDF}$ & 81 & 73 & 84 \\
\hline${ }^{13} C_{12}-2,3,7,8-T C D D$ & 80 & 85 & 88 \\
\hline${ }^{13} C_{12}-1,2,3,7,8-P \in C D F$ & 83 & 73 & 85 \\
\hline${ }^{13} \mathrm{C}_{12}-1,2,3,7,8-\mathrm{PeCDD}$ & 79 & 70 & 85 \\
\hline${ }^{13} \mathrm{C}_{12}-1,2,3,4,7,8-\mathrm{H} \times \mathrm{CDF}$ & 81 & 71 & 83 \\
\hline${ }^{13} \mathrm{C}_{12}-1,2,3,6,7,8-\mathrm{H} \times \mathrm{CDD}$ & 78 & 69 & 72 \\
\hline${ }^{13} \mathrm{C}_{12}-1,2,3,4,6,7,8-\mathrm{HpCDF}$ & 71 & 62 & 72 \\
\hline${ }^{13} C_{12}-1,2,3,4,1,7, \& H p C D D$ & 72 & 74 & 75 \\
\hline${ }^{13} \mathrm{C}_{12}-\mathrm{OCDD}$ & 70 & 59 & 70 \\
\hline \multicolumn{4}{|c|}{ CONCENTRATIONS DETECTED OR MLD $\left(\mathrm{gg} / \mathrm{m}^{3}\right)$} \\
\hline (TOTAL) & $N D(0.03)$ & $N D(0.02)$ & 153 \\
\hline $2,3,7,8-T C D D$ & $\mathrm{ND}(0.03)$ & $\mathrm{ND}(0.02)$ & 0.68 \\
\hline (TOTAL) & $\mathrm{ND}(0.02)$ & $\mathrm{ND}(0.03)$ & 1.89 \\
\hline $1,2,3,7,8-P \in C D D$ & $N D(0.02)$ & $\mathrm{ND}(0.03)$ & 0.65 \\
\hline (TOTAL) & 0.06 & 0.12 & 3.25 \\
\hline $1,2,3,4,7,8-\mathrm{H} \times C D D$ & $\mathrm{ND}(0.02)$ & $N D(0.03)$ & 0.65 \\
\hline $1,2,3,6,7,8-\mathrm{H} x \mathrm{CDD}$ & $\mathrm{ND}(0.02)$ & $\mathrm{ND}(0.03)$ & 0.65 \\
\hline $1,2,3,7,8,9-\mathrm{H} \times \mathrm{CDD}$ & $\mathrm{ND}(0.02)$ & $N D(0.03)$ & 0.72 \\
\hline (TOTAL) & 0.12 & 0.12 & 1.87 \\
\hline $1,2,3,4,6,7,8-\mathrm{HPCDD}$ & 0.05 & 0.06 & 1.25 \\
\hline OCDD & 0.31 & 0.34 & 1.64 \\
\hline (TOTAL) & $\mathrm{ND}(0.02)$ & $N D(0.05)$ & 1.53 \\
\hline $2,3,7,8-\mathrm{TCDF}$ & $\mathrm{ND}(0.02)$ & $\mathrm{ND}(0.05)$ & 0.63 \\
\hline (TOTAL) & $\mathrm{ND}(0.02)$ & $\mathrm{ND}(0.03)$ & 2.29 \\
\hline $1,2,3,7,8-\mathrm{PeCDF}$ & $N D(0.02)$ & $\mathrm{ND}(0.03)$ & 0.62 \\
\hline $2,3,4,7,8-\mathrm{PeCDF}$ & $\mathrm{ND}(0.02)$ & $N D(0.03)$ & 0.64 \\
\hline HxCDFs & $N D(0.02)$ & $N D(0.03)$ & 3.60 \\
\hline $1,2,3,4,7,8-\mathrm{H} \times \mathrm{CDF}$ & $\mathrm{ND}(0.02)$ & $\mathrm{ND}(0.03)$ & $\cdot 0.65$ \\
\hline $1,2,3,6,7,8-\mathrm{H} \times C D F$ & $N D(0.02)$ & $N D(0.03)$ & 0.65 \\
\hline $1,2,3,7,8,9-\mathrm{H} \times C D F$ & $\mathrm{ND}(0.02)$ & $N D(0.03)$ & 0.57 \\
\hline $2,3,4,6,7,8-\mathrm{H} x \mathrm{CDF}$ & $\mathrm{ND}(0.02)$ & $\mathrm{ND}(0.03)$ & 0.59 \\
\hline HpCDFs & $\mathrm{ND}(0.03)$ & $\mathrm{ND}(0.05)$ & 2.40 \\
\hline $1,2,3,4,6,7,8-\mathrm{HpCDF}$ & $\mathrm{ND}(0.03)$ & $N D(0.02)$ & 1.15 \\
\hline $1,2,3,4,7,8,9-\mathrm{HpCDF}$ & $\mathrm{ND}(0.03)$ & $N D(0.02)$ & 1.25 \\
\hline OCDF & 0.04 & 0.05 & 1.38 \\
\hline
\end{tabular}

$N D=$ Not detected at specified minimum limit of detection (MLD).

Note: Please refer to text for discussion and qualification that must accompany the results.

Total = All congeners, including the 2,3,7,8-substituted congeners.

-F883 = BIF01, Antartica air, field blank. ${ }^{\mathrm{a}}$

F-892 = Laboratory method blank. ${ }^{2}$

F-893 = Laboratory forified method biank.

$=400 \mathrm{~m}^{3}$ air used for calculation of concentrations. 
TABLE 3. Analyrical Results for PCDDs and PCDFs in Ambient Air Samples from Antartica

\begin{tabular}{|c|c|c|c|c|}
\hline IDENTIFICATION" & $F-899$ & $F-900$ & F.901 & F-902 \\
\hline \multicolumn{5}{|c|}{ PS-1 AIR SAMPLER EFFICIENCY (\% RECOVERY) } \\
\hline${ }^{13} \mathrm{C}_{12}-1,2,3,4 \mathrm{TCDD}$ & 97 & 93 & 93 & 94 \\
\hline \multicolumn{5}{|c|}{ METHOD EFFICIENCY (\% RECOVERY) } \\
\hline${ }^{13} \mathrm{C}_{12}-2,3,7,8-\mathrm{TCDF}$ & 91 & 90 & 85 & 86 \\
\hline${ }^{13} \mathrm{C}_{12}-2,3,7,8-\mathrm{TCDD}$ & 97 & 101 & 103 & 102 \\
\hline${ }^{13} \mathrm{C}_{12}-1,2,3,7,8 \mathrm{PeCDF}$ & 90 & 91 & 89 & 90 \\
\hline${ }^{13} C_{12}-1,2,3,7,8-P e C D D$ & 85 & 90 & 88 & 92 \\
\hline${ }^{13} \mathrm{C}_{12}-1,2,3,4,7,8-\mathrm{H} \times \mathrm{CDF}$ & 85 & 98 & 88 & 89 \\
\hline${ }^{{ }^{13}} \mathrm{C}_{12}-1,2,3,6,7,8-\mathrm{H} x \mathrm{CDD}$ & 83 & 90 & 85 & 89 \\
\hline${ }^{13} \mathrm{C}_{12}-1,2,3,4,6,7,8-\mathrm{HpCDF}$ & 76 & 85 & 84. & 79 \\
\hline${ }^{13} \mathrm{C}_{12}-1,2,3,4,6,7,8-\mathrm{HPCDD}$ & 78 & 89 & 88 & 89 \\
\hline${ }^{13} \mathrm{C}_{12}-\mathrm{OCDD}$ & 72 & 85 & 89 & 82 \\
\hline \multicolumn{5}{|c|}{ CONCENTRATIONS DETECTED OR MLD $\left(\mathrm{pg} / \mathrm{m}^{3}\right)$} \\
\hline (TOTAL) & $\mathrm{ND}(0.01)$ & $\mathrm{ND}(0.02)$ & 0.48 & $\mathrm{ND}(0.02)$ \\
\hline 2.3.7,8-TCDD & $\mathrm{ND}(0.01)$ & $N D(0.02)$ & 0.01 & $\mathrm{ND}(0.02)$ \\
\hline (TOTAL) & $\mathrm{ND}(0.02)$ & $\mathrm{ND}(0.01)$ & 0.42 & $\mathrm{ND}(0.02)$ \\
\hline 1,2,3,7,8-PeCDD & $\mathrm{ND}(0.02)$ & $N D(0.01)$ & 0.02 & $\mathrm{ND}(0.02)$ \\
\hline (TOTAL) & $\mathrm{ND}(0.02)$ & $N D(0.03)$ & 0.41 & $\mathrm{ND}(0.08)$ \\
\hline $1,2,3,4,7,8-\mathrm{H} x \mathrm{CDD}$ & $\mathrm{ND}(0.02)$ & $\mathrm{ND}(0.03)$ & 0.02 & $\mathrm{ND}(0.02)$ \\
\hline $1,2,3,6,7,8-\mathrm{HxCDD}$ & $\mathrm{ND}(0.02)$ & $N D(0.03)$ & 0.04 & $\mathrm{ND}(0.02)$ \\
\hline $1,2,3,7,8,9-\mathrm{H} \times \mathrm{CDD}$ & $\mathrm{ND}(0.02)$ & $\mathrm{ND}(0.03)$ & 0.04 & $\mathrm{ND}(0.02)$ \\
\hline (TOTAL) & 0.06 & 0.04 & 0.23 & 0.12 \\
\hline $1,2,3,4,6,7,8-\mathrm{HpCDD}$ & 0.03 & 0.02 & 0.13 & 0.05 \\
\hline OCDD & 0.15 & 0.09 & 0.41 & 0.30 \\
\hline (TOTAL) & $\mathrm{ND}(0.02)$ & $\mathrm{ND}(0.02)$ & 1.51 & $\mathrm{ND}(0.04)$ \\
\hline $2,3,7,8-\mathrm{TCDF}$ & $\mathrm{ND}(0.02)$ & $\mathrm{ND}(0.02)$ & 0.11 & $\mathrm{ND}(0.04)$ \\
\hline (TOTAL) & $\mathrm{ND}(0.08)$ & $\mathrm{ND}(0.02)$ & 0.90 & $\mathrm{ND}(0.02)$ \\
\hline $1,2,3,7,8-\mathrm{PeCDF}$ & $\mathrm{ND}(0.008)$ & $\mathrm{ND}(0.02)$ & 0.07 & $\mathrm{ND}(0.02)$ \\
\hline $2,3,4,7,8 \cdot P e C D F$ & $\mathrm{ND}(0.008)$ & $\mathrm{ND}(0.02)$ & 0.08 & $\mathrm{ND}(0.02)$ \\
\hline (TOTAL) & $\mathrm{ND}(0.02)$ & $\mathrm{ND}(0.03)$ & 0.23 & $\mathrm{ND}(0.01)$ \\
\hline $1,2,3,4,7,8-\mathrm{HxCDF}$ & $N D(0.02)$ & $\mathrm{ND}(0.03)$ & 0.05 & $\mathrm{ND}(0.01)$ \\
\hline $1,2,3,6,7,8-\mathrm{H} x \mathrm{CDF}$ & $\mathrm{ND}(0.02)$ & $\mathrm{ND}(0.03)$ & 0.05 & $\mathrm{ND}(0.01)$ \\
\hline $1,2,3,7,8,9-\mathrm{H} x \mathrm{CDF}$ & $\mathrm{ND}(0.02)$ & $\mathrm{ND}(0.03)$ & $\mathrm{ND}(0.008)$ & $\mathrm{ND}(0.01)$ \\
\hline $2,3,4,6,7,8 \mathrm{H} \times \mathrm{CDF}$ & $\mathrm{ND}(0.02)$ & $\mathrm{ND}(0.03)$ & $\mathrm{ND}(0.008)$ & $\mathrm{ND}(0.01)$ \\
\hline HpCDFs & 0.25 & $\mathrm{ND}(0.01)$ & 0.12 & $\mathrm{ND}(0.02)$ \\
\hline $1,2,3,4,6,7,8-\mathrm{HpCDF}$ & 0.14 & $\mathrm{ND}(0.01)$ & 0.09 & $\mathrm{ND}(0.02)$ \\
\hline $1,2,3,4,7,8,9-\mathrm{HpCDF}$ & $N D(0.02)$ & $\mathrm{ND}(0.01)$ & $\mathrm{ND}(0.009)$ & $\mathrm{ND}(0.02)$ \\
\hline OCDF & 0.74 & 0.03 & 0.04 & 0.04 \\
\hline
\end{tabular}
ND $\quad=\quad$ Not detected at specified minimum limit of detection (MLD)
(TOTAL) $=\quad$ All congeners, including the 2,3,7,8-substituted congeners.
- F-899 = HPDOS, Antaretica air, $373.7 \mathrm{~m}^{3}$
F.900 = TSD04, Antartica air, $387.7 \mathrm{~m}^{3}$
F-901 = MCD03, Antaretica air, $744.3 \mathrm{~m}^{3}$
F-902 = MCDOS, Antaretica air, $398.8 \mathrm{~m}^{3}$ 
TABLE 4. Analytical Results for PCDDs and PCDFs in Ambient Air Samples from Antartica

\begin{tabular}{|c|c|c|c|c|}
\hline \multicolumn{2}{|c|}{ IDENIIFICATION* } & F-903 & F.904 & F-905 \\
\hline \multicolumn{5}{|c|}{ PS-1 AIR SAMPLER EFFICIENCY (\% RECOVERY) } \\
\hline${ }^{13} C_{12}-1.2$ & $\mathrm{CDD}$ & 93 & 88 & 85 \\
\hline \multicolumn{5}{|c|}{ METHOD EFFICIENCY (\% RECOVERY) } \\
\hline${ }^{13} C_{12-2,3}$ & $\mathrm{CDF}$ & 88 & 82 & 84 \\
\hline${ }^{13} \mathrm{C}_{12}-2,3$ & $C D D$ & 103 & 104 & 100 \\
\hline${ }^{13} c_{12-1,2}$ & $\mathrm{PeCDF}$ & 84 & 87 & 88 \\
\hline${ }^{13} C_{12}-12$ & $P C C D D$ & 82 & 86 & 87 \\
\hline${ }^{13} c_{12-1,2}$ & 8-HXCDF & 80 & 92 & 86 \\
\hline${ }^{13} C_{12-1,2}$ & 8-HXCDD & 78 & 89 & 83 \\
\hline${ }^{13} C_{12-1,2}$ & $7,8-\mathrm{HPCDF}$ & 72 & 85 & 75 \\
\hline${ }^{13} c_{12-1,2}$ & $7,8-\mathrm{H}_{\mathrm{fCDD}}$ & $\pi$ & 91 & 79 \\
\hline${ }^{13} \mathrm{C}_{12}-\mathrm{OC}$ & & 71 & 89 & 72 \\
\hline \multicolumn{5}{|c|}{ CONCENTRATIONS DETECIED OR MLD $\left(\mathrm{pg} / \mathrm{m}^{3}\right)$} \\
\hline TCDDs & (TOTAL) & $\mathrm{ND}(0.005)$ & 155 & $\mathrm{ND}(0.01)$ \\
\hline $2,3.7 .8 \mathrm{TCI}$ & & $\mathrm{ND}(0.005)$ & 0.63 & $\mathrm{ND}(0.01)$ \\
\hline PeCDDs & (TOTAL) & $\mathrm{ND}(0.01)$ & 1.96 & $\mathrm{ND}(0.02)$ \\
\hline $1,2,3.7,8-\mathrm{Pe}$ & & $\mathrm{ND}(0.01)$ & 0.64 & $\mathrm{ND}(0.02)$ \\
\hline HxCDDs & (TOTAL) & $\mathrm{ND}(0.01)$ & 2.99 & $\mathrm{ND}(0.03)$ \\
\hline $1,2,3,4,7,8-1$ & & $\mathrm{ND}(0.01)$ & 0.64 & $N D(0.03)$ \\
\hline $1,2,3,6,7,8-1$ & & $\mathrm{ND}(0.01)$ & 0.64 & $\mathrm{ND}(0.03)$ \\
\hline $1,2,3,7,8,9-1$ & & $N D(0.01)$ & 0.63 & $\mathrm{ND}(0.03)$ \\
\hline HpCDDs & (TOTAL) & 0.02 & 1.66 & 0.05 \\
\hline $1,2,3,4,6,7,8$ & $\angle D D$ & 0.01 & 1.15 & 0.03 \\
\hline OCDD & & 0.07 & 1.15 & 0.10 \\
\hline TCDFs & (TOTAL) & $\mathrm{ND}(0.02)$ & 155 & $\mathrm{ND}(0.03)$ \\
\hline $2,3,7,8-\mathrm{TCI}$ & & $\mathrm{ND}(0.02)$ & 0.66 & $\mathrm{ND}(0.03)$ \\
\hline PeCDFs & (TOTAL) & $\mathrm{ND}(0.006)$ & 2.30 & $\mathrm{ND}(0.009)$ \\
\hline $1,2,3,7,8-\mathrm{PC}$ & & $\mathrm{ND}(0.006)$ & 0.65 & $N D(0.009)$ \\
\hline $2,3,4,7,8-\mathrm{Pe}$ & & $\mathrm{ND}(0.006)$ & 0.64 & $\mathrm{ND}(0,009)$ \\
\hline HxCDFs & (TOTAL) & $\mathrm{ND}(0.007)$ & 351 & $\mathrm{ND}(0.01)$ \\
\hline $1,2,3,4,7,8-1$ & & $\mathrm{ND}(0.007)$ & 0.66 & $\mathrm{ND}(0.01)$ \\
\hline $12,3,6,7,8-$ & & $\mathrm{ND}(0.007)$ & 0.65 & $\mathrm{ND}(0.01)$ \\
\hline $1,2,3,7,8,9-1$ & & $\mathrm{ND}(0.007)$ & 0.58 & $\mathrm{ND}(0.01)$ \\
\hline $2,3,4,6,7,8$ & & $N D(0.007)$ & 0.58 & $\mathrm{ND}(0.01)$ \\
\hline HpCDFs & (TOTAL) & $\mathrm{ND}(0.01)$ & 234 & $\mathrm{ND}(0.02)$ \\
\hline $1,2,3,4,6,7,8$ & CDF & $\mathrm{ND}(0.01)$ & 1.08 & $\mathrm{ND}(0.02)$ \\
\hline $1,23.4,7,8,5$ & CDF & $\mathrm{ND}(0.01)$ & 1.26 & $\mathrm{ND}(0.02)$ \\
\hline $\mathrm{OCDF}$ & & 0.02 & 1.15 & 0.03 \\
\hline $\begin{array}{l}\text { ND } \\
\text { TOTAL } \\
\text {-F.903 } \\
\text { F.904 } \\
\text { F-905 }\end{array}$ & $\begin{array}{l}=\text { Not detected at specifie } \\
=\text { All congeners, includin } \\
=\text { Laboratory method bla } \\
=\text { Laboratory fortified me } \\
=\text { Field blank. } \\
=400 \mathrm{~m}^{3} \text { air used for }\end{array}$ & $\begin{array}{l}\text { mum limit of } \\
3,7,8 \text {-substitu } \\
\text { lank. }\end{array}$ & & \\
\hline
\end{tabular}


TABLE 5. Analytical Results for PCDDs and PCDFs in Ambient Air Samples from Antarctica

\begin{tabular}{|c|c|c|c|c|c|}
\hline IDENTIFICATION & F-906 & F.907 & F-908 & F-909 & F-910 \\
\hline \multicolumn{6}{|c|}{ PS-1 AIR SAMPLER EFFICIENCY (\% RECOVERY) } \\
\hline${ }^{13} \mathrm{C}_{12}-1,2,3,4 \mathrm{TCDD}$ & 88 & 102 & 104 & 95 & 89 \\
\hline \multicolumn{6}{|c|}{ MEIHOD EFFICIENCY (\% RECOVERY) } \\
\hline${ }^{13} \mathrm{C}_{12}-2,3,7,8-\mathrm{TCDF}$ & 86 & 86 & 74 & 89 & 90 \\
\hline${ }^{13} \mathrm{C}_{12}-2,3,7,8-\mathrm{TCDD}$ & 102 & 91 & 76 & 103 & 108 \\
\hline${ }^{13} \mathrm{C}_{12}-1,2,3,7,8-\mathrm{PeCDF}$ & 89 & 87 & 73 & 94 & 96 \\
\hline${ }^{13} \mathrm{C}_{12}-1,2,3,7,8-\mathrm{PeCDD}$ & 89 & 86 & 70 & 92 & 93 \\
\hline${ }^{13} \mathrm{C}_{12}-1,2,3,4,7,8-\mathrm{H} \mathrm{x} \mathrm{CDF}$ & 94 & 90 & 75 & 90 & 97 \\
\hline${ }^{13} \mathrm{C}_{12}-1,2,3,6,7,8-\mathrm{H} x \mathrm{CDD}$ & 89 & 93 & 71 & 91 & 96 \\
\hline${ }^{13} \mathrm{C}_{12}-1,2,3,4,6,7,8-\mathrm{H} F \mathrm{CDF}$ & 86. & 84 & 67 & 83 & 95 \\
\hline${ }^{13} \mathrm{C}_{12}-1,2,3,4,6,7,8-\mathrm{HpCDD}$ & 89 & 89 & 73 & 88 & 95 \\
\hline${ }^{13} \mathrm{C}_{12}-\mathrm{OCDD}$ & 83 & 93 & 69 & 82 & 89 \\
\hline \multicolumn{6}{|c|}{ CONCENTRATIONS DETECTED OR MLD $\left(\mathrm{pg} / \mathrm{m}^{3}\right)$} \\
\hline (TOTAL) & $\mathrm{ND}(0.006)$ & $\mathrm{ND}(0.03)$ & $\mathrm{ND}(0.02)$ & $\mathrm{ND}(0.01)$ & $\mathrm{ND}(0.02)$ \\
\hline $2,3,7,8-T C D D$ & $\mathrm{ND}(0.006)$ & $\mathrm{ND}(0.03)$ & $\mathrm{ND}(0.02)$ & $\mathrm{ND}(0.01)$ & $\mathrm{ND}(0.02)$ \\
\hline (TOTAL) & $\mathrm{ND}(0.005)$ & $\mathrm{ND}(0.02)$ & $\mathrm{ND}(0.01)$ & $\mathrm{ND}(0.01)$ & $\mathrm{ND}(0.01)$ \\
\hline 1,2.3,7,8-PeCDD & $\mathrm{ND}(0.005)$ & $\mathrm{ND}(0.02)$ & $\mathrm{ND}(0.01)$ & $\mathrm{ND}(0.01)$ & $\mathrm{ND}(0.01)$ \\
\hline (TOTAL) & $\mathrm{ND}(0.02)$ & $\mathrm{ND}(0.03)$ & $\mathrm{ND}(0.009)$ & $\mathrm{ND}(0.01)$ & $\mathrm{ND}(0.06)$ \\
\hline 1,2.3,4.7,8-HxCDD & $\mathrm{ND}(0.02)$ & $\mathrm{ND}(0.03)$ & $\mathrm{ND}(0.009)$ & $N D(0.01)$ & $\mathrm{ND}(0.01)$ \\
\hline 1,2,3,6,7,8-HxCDD & $\mathrm{ND}(0.02)$ & $\mathrm{ND}(0.03)$ & $\mathrm{ND}(0.009)$ & $\mathrm{ND}(0.01)$ & $\mathrm{ND}(0.01)$ \\
\hline 1,2,3,7,8,9-HxCDD & $\mathrm{ND}(0.02)$ & $\mathrm{ND}(0.03)$ & $\mathrm{ND}(0.009)$ & $\mathrm{ND}(0.01)$ & $\mathrm{ND}(0.01)$ \\
\hline (TOTAL) & 0.03 & 0.13 & 0.10 & $\mathrm{ND}(0.03)$ & 0.11 \\
\hline $1,2,3,4,6,7,8-\mathrm{HpCDD}$ & 0.01 & 0.06 & 0.05 & $\mathrm{ND}(0.01)$ & 0.06 \\
\hline OCDD & 0.05 & 0.38 & 0.13 & 0.05 & 0.20 \\
\hline (TOTAL) & $\mathrm{ND}(0.02)$ & $\mathrm{ND}(0.02)$ & $\mathrm{ND}(0.02)$ & $\mathrm{ND}(0.01)$ & $\mathrm{ND}(0.01)$ \\
\hline $2,3,7,8-\mathrm{TCDF}$ & $\mathrm{ND}(0.02)$ & $\mathrm{ND}(0.02)$ & $\mathrm{ND}(0.02)$ & $\mathrm{ND}(0.01)$ & $\mathrm{ND}(0.01)$ \\
\hline (TOTAL) & $\mathrm{ND}(0.007)$ & $\mathrm{ND}(0.01)$ & $\mathrm{ND}(0.01)$ & $\mathrm{ND}(0.01)$ & $\mathrm{ND}(0.01)$ \\
\hline $1,2,3,7,8-\mathrm{PeCDF}$ & $\mathrm{ND}(0.007)$ & $\mathrm{ND}(0.01)$ & $\mathrm{ND}(0.01)$ & $\mathrm{ND}(0.01)$ & $\mathrm{ND}(0.01)$ \\
\hline $2,3,4,7,8-\mathrm{PeCDF}$ & $\mathrm{ND}(0.007)$ & $\mathrm{ND}(0.001)$ & $\mathrm{ND}(0.01)$ & $\mathrm{ND}(0.01)$ & $N D(0.01)$ \\
\hline (IOTAL) & $\mathrm{ND}(0.009)$ & $\mathrm{ND}(0.02)$ & $\mathrm{ND}(0.02)$ & $\mathrm{ND}(0.01)$ & $\mathrm{ND}(0.01)$ \\
\hline $1,2,3,4,7,8-\mathrm{HxCDF}$ & $\mathrm{ND}(0.009)$ & $\mathrm{ND}(0.02)$ & $\mathrm{ND}(0.02)$ & $\mathrm{ND}(0.01)$ & $\mathrm{ND}(0.01)$ \\
\hline $1,2,3,6,7,8-\mathrm{H} \times \mathrm{CDF}$ & $\mathrm{ND}(0.009)$ & $\mathrm{ND}(0.02)$ & $\mathrm{ND}(0.02)$ & $\mathrm{ND}(0.01)$ & $\mathrm{ND}(0.01)$ \\
\hline $1,2,3,7,8,9-\mathrm{H} 4 \mathrm{CDF}$ & $\mathrm{ND}(0.009)$ & $\mathrm{ND}(0.02)$ & $\mathrm{ND}(0.02)$ & $\mathrm{ND}(0.01)$ & $\mathrm{ND}(0.01)$ \\
\hline $2,3,4,6,7,8-\mathrm{H} \times \mathrm{CDF}$ & $\mathrm{ND}(0.009)$ & $\mathrm{ND}(0.02)$ & $\mathrm{ND}(0.02)$ & $\mathrm{ND}(0.01)$ & $\mathrm{ND}(0.01)$ \\
\hline (TOTAL) & $\mathrm{ND}(0.009)$ & $\mathrm{ND}(0.01)$ & 0.01 & $\mathrm{ND}(0.01)$ & 0.01 \\
\hline $1,2,3,4,6,7,8-\mathrm{HpCDF}$ & $\mathrm{ND}(0.009)$ & $\mathrm{ND}(0.01)$ & 0.01 & $\mathrm{ND}(0.01)$ & 0.01 \\
\hline $1,2,3,4,7,8,9-\mathrm{HpCDF}$ & $\mathrm{ND}(0.009)$ & $\mathrm{ND}(0.01)$ & $\mathrm{ND}(0.01)$ & $\mathrm{ND}(0.01)$ & $\mathrm{ND}(0.01)$ \\
\hline OCDF & $\mathrm{ND}(0.02)$ & $\mathrm{ND}(0.03)$ & 0.02 & $\mathrm{ND}(0.03)$ & $\mathrm{ND}(0.02)$ \\
\hline
\end{tabular}

ND = Not detected at specified minimum limit of detection (MLD).

(TOTAL) = All congeners, including the 2,3,7,8-substituted congeners.

-F-906 = TSD02, Antartica air, $78.7 \mathrm{~m}^{3} \quad$ F-909 = TSD03, Antarctica air, $804.9 \mathrm{~m}^{3}$

F-907 = MCD04, Antartica air, $813.3 \mathrm{~m}^{3} \quad$ F-910 = HPD04, Antartica air, $783.4 \mathrm{~m}^{3}$

F-908 $=$ HPDO3, Antartica air. $743.3 \mathrm{~m}^{3}$ 